\title{
ROS Generation and Antioxidant Defense Systems in Normal and Malignant Cells
}

\author{
Anastasiya V. Snezhkina (D), Anna V. Kudryavtseva (D), Olga L. Kardymon, \\ Maria V. Savvateeva (D), Nataliya V. Melnikova (D), George S. Krasnov (D, \\ and Alexey A. Dmitriev (D)
}

Engelhardt Institute of Molecular Biology, Russian Academy of Sciences, Moscow 119991, Russia

Correspondence should be addressed to Anastasiya V. Snezhkina; leftger@rambler.ru and Alexey A. Dmitriev; alex_245@mail.ru Received 5 April 2019; Accepted 24 June 2019; Published 5 August 2019

Academic Editor: Maria Isaguliants

Copyright ( 2019 Anastasiya V. Snezhkina et al. This is an open access article distributed under the Creative Commons Attribution License, which permits unrestricted use, distribution, and reproduction in any medium, provided the original work is properly cited.

\begin{abstract}
Reactive oxygen species (ROS) are by-products of normal cell activity. They are produced in many cellular compartments and play a major role in signaling pathways. Overproduction of ROS is associated with the development of various human diseases (including cancer, cardiovascular, neurodegenerative, and metabolic disorders), inflammation, and aging. Tumors continuously generate ROS at increased levels that have a dual role in their development. Oxidative stress can promote tumor initiation, progression, and resistance to therapy through DNA damage, leading to the accumulation of mutations and genome instability, as well as reprogramming cell metabolism and signaling. On the contrary, elevated ROS levels can induce tumor cell death. This review covers the current data on the mechanisms of ROS generation and existing antioxidant systems balancing the redox state in mammalian cells that can also be related to tumors.
\end{abstract}

\section{Introduction}

Reactive oxygen species (ROS) are formed as natural by-products of normal cell activity and participate in cellular signaling [1]. The increase in ROS levels has harmful effects on cell homeostasis, structures, and functions and results in oxidative stress. As such, the disturbance of cellular redox balance is a risk factor for the development of various pathologies [2].

Tumor cells are characterized by a high level of ROS. ROS overproduction can result from changes in many processes, such as oxidative phosphorylation (OXPHOS), transition metal ions, oxidase activity, protein folding, thymidine, and polyamine catabolism [3-7]. ROS can be generated both in various cellular compartments and in the tumor microenvironment.

ROS have a dual role in cancer development; on one hand, they can promote molecular genetic alterations that are necessary for tumor initiation, growth, and progression, as well as acquisition of treatment resistance [8]. On the other hand, permanent elevated ROS levels have cytotoxic effects, inducing activation of apoptotic pathways or inhibiting resistance to anticancer treatments [9].

In this review, we discuss the main sources of ROS production in animal cells and the antioxidant defense systems that could be implicated in the redox state of cancer cells (to a significant or less significant extent).

\section{Sources of ROS Generation and Antioxidant Defense Systems}

2.1. Mitochondria. Mitochondria are a prime source of endogenous ROS due to its main role in oxidative ATP production, in which molecular oxygen $\left(\mathrm{O}_{2}\right)$ is reduced to water in the electron transport chain. The superoxide radical $\left(\mathrm{O}_{2}{ }^{--}\right)$ is produced at a number of sites in the mitochondria, including complex I (sites IQ and IF), complex III (site IIIQo), glycerol 3-phosphate dehydrogenase, Q oxidoreductase, pyruvate 
dehydrogenase, and 2-oxoglutarate dehydrogenase [10]. All the sites release superoxide radical into the mitochondrial matrix (MM), and two of them, complex III (site IIIQo) and glycerol 3-phosphate dehydrogenase, also generate ROS into the intermembrane mitochondrial space (IMS). Manganese superoxide dismutase (Mn-SOD) converts the superoxide radical to hydrogen peroxide $\left(\mathrm{H}_{2} \mathrm{O}_{2}\right)$ in the $\mathrm{MM}$, while $\mathrm{Cu}$ - and $\mathrm{Zn}-\mathrm{SOD}$ convert the superoxide radical in the IMS or cytosol [11]. The $\mathrm{H}_{2} \mathrm{O}_{2}$ in the MM can further be converted by mitochondrial aconitase to a hydroxyl radical $\left({ }^{\circ} \mathrm{OH}\right)$ via a Fenton reaction [12]. One more site of ROS production in the mitochondria is the cytochrome (CYP) catalytic cycle. CYP enzymes metabolize a wide range of organic substrates (lipids, steroid hormones, xenobiotics, and others) to give rise to superoxide radical and $\mathrm{H}_{2} \mathrm{O}_{2}$ as by-products [13]. Several CYP family members were shown to be present in the mitochondrial membrane of steroidogenic organs, as well as in the liver and kidney [14]. Furthermore, several other mammalian proteins, such as NADH-cytochrome $b 5$ reductase [15], dihydroorotate dehydrogenase [16, 17], complex II (succinate dehydrogenase) [18], and monoamine oxidases (MAO) [19], were shown to generate ROS in the mitochondria.

Mitochondria are protected from ROS by multiple defense systems and antioxidants: glutathione peroxidases (GPXs), thioredoxin peroxidases (TRXPs), superoxide dismutases (SODs), peroxiredoxins (PRDXs), glutathione (GSH), thioredoxin 2 (TRX2), glutaredoxin 2 (GRX2), cytochrome c oxidase (complex IV), coenzyme Q, ascorbic acid, tocopherol, vitamin E, and carotene [20-26]. Moreover, catalase (CAT), which commonly detoxifies $\mathrm{H}_{2} \mathrm{O}_{2}$ in the peroxisome, was found in rat heart mitochondria (but not in other tissues) [27, 28].

Mitochondrion-generated ROS were widely shown to be implicated in various human pathologies, including inflammation, cancer, mitochondrial and neurodegenerative diseases, diabetes, chronic diseases, and aging [3, 29-32]. Elevated ROS levels and mitochondrial dysfunction, present in many cancers, lead to oxidative damage of cellular structures, in particular, genomic and mitochondrial DNA, somatic mutations, genome instability, activation of oncogenes and inactivation of tumor suppressor genes, and alterations in metabolic and signaling pathways with simultaneous activation of compensatory antioxidant mechanisms, that all contribute to cell transformation [33]. However, overproduction of ROS can also promote tumor cell apoptosis and such strategies have effectively been used for anticancer treatment [34].

2.2. Transition Metal Ions. One of the major mechanisms of metal carcinogenicity is the ability of transition metal ions to induce oxidative stress [35]. Fenton and Haber-Weiss reactions are frequently responsible for ROS generation in living cells [36]. During these reactions, $\mathrm{H}_{2} \mathrm{O}_{2}$ is decomposed with the participation of metal ions, such as iron $(\mathrm{Fe})$, copper $(\mathrm{Cu})$, zinc $(\mathrm{Zn})$, and aluminum $(\mathrm{Al})$, leading to the production of hydroxyl radical $\left({ }^{\circ} \mathrm{OH}\right)$ and hydroxyl anion $\left(\mathrm{OH}^{-}\right)$[37]. Other carcinogenic metal ions (antimony, arsenic, chromium, cobalt, nickel, and vanadium) were also supposed to be able to generate ROS in cellular redox reactions [36]. The hydroxyl radicals produced can attack the DNA, causing oxidative DNA adduct formation. The adducts 8 -hydroxy- 2 -deoxyguanosine $(8-\mathrm{OHdG})$ and 8-oxo-7,8-dihydro- $2^{\prime}$-deoxyguanosine (8-oxodG) are the most predominant, resulting from the addition of hydroxyl radicals to guanine. These compounds are widely considered as markers of endogenous oxidative DNA damage as well as a risk factor for cancer development [38].

2.3. Peroxisome Activity. Peroxisomes have multiple functions in living cells, including fatty acid $\beta$-oxidation and $\alpha$-oxidation as well as metabolism of purines, polyamines, amino acids, glyoxylate, reactive oxygen and nitrogen species (RNS), transition metal ions, and others [39, 40]. Peroxisomes generate a wide range of ROS and RNS: $\mathrm{H}_{2} \mathrm{O}_{2}$, superoxide radical $\left(\mathrm{O}_{2}{ }^{\bullet-}\right)$, hydroxyl radical $\left({ }^{\bullet} \mathrm{OH}\right)$, nitric oxide $\left(\mathrm{NO}^{\bullet}\right)$, and peroxynitrite $\left(\mathrm{ONOO}^{-}\right)$[41].

The peroxisome was first described as an $\mathrm{H}_{2} \mathrm{O}_{2}$-producing and $\mathrm{H}_{2} \mathrm{O}_{2}$-degrading organelle [42]. Despite the presence of CAT, peroxisomes are one of the main sources of $\mathrm{H}_{2} \mathrm{O}_{2}$ $[43,44] . \mathrm{H}_{2} \mathrm{O}_{2}$ is released as a by-product during the normal catalytic activity of many peroxisomal enzymes, and it can also be generated by the spontaneous or enzymatic dismutation of the superoxide radical [45]. $\mathrm{H}_{2} \mathrm{O}_{2}$ can generate hydroxyl radicals $\left({ }^{\circ} \mathrm{OH}\right)$ via a Fenton reaction [46].

Peroxisomes produce superoxide radicals $\left(\mathrm{O}_{2}{ }^{--}\right)$in both the matrix and membrane. In the matrix, two enzymes are responsible for $\mathrm{O}_{2}{ }^{\bullet-}$ generation, xanthine oxidoreductase (XOR), and urate oxidase (UO) $[47,48]$. XOR catalyzes the formation of uric acid during purine metabolism that is further converted to allantoin by UO. Both enzymes generate $\mathrm{O}_{2}{ }^{\bullet-}$ and $\mathrm{H}_{2} \mathrm{O}_{2}$. However, $\mathrm{UO}$ expression was not detected in humans and some primates indicating that uric acid is a terminal compound of purine metabolism [49]. The other source of superoxide radicals is an electron transport chain in the peroxisomal membrane [50]. Moreover, XOR also catalyzes the reduction of nitrates and nitrites to nitric oxide $\left(\mathrm{NO}^{\bullet}\right)$ [51]. $\mathrm{NO}^{\bullet}$ can also be produced from L-arginine, in a reaction catalyzed by nitric oxide synthase (NOS) [52]. The reaction of $\mathrm{O}_{2}{ }^{--}$with $\mathrm{NO}^{\bullet}$ results in a highly reactive compound called peroxynitrite $\left(\mathrm{ONOO}^{-}\right)$[53].

Several antioxidant systems regulate ROS levels in peroxisomes and defend cells from oxidative damage. These include a number of enzymes, such as CAT, superoxide dismutases, peroxiredoxins, glutathione S-transferases (GST), and epoxide hydrolase 2 (EPHX2), as well as nonenzymatic low-molecular weight antioxidants, which are reviewed in detail elsewhere $[39,45,50]$.

Changes in redox homeostasis contribute to cancer development and progression [54]. The peroxisome maintains cellular oxidative balance, and dysregulation of its activity is associated with carcinogenesis. Thus, reduced CAT activity leads to ROS generation and oxidative stress resulting in DNA damage and genome instability promoting cancer development. Decreased CAT expression has been shown in hepatocellular carcinoma and colon, lung, kidney, and prostate cancers, as well as in precancer states, such 
as prostatic intraepithelial neoplasia (PIN) and cervical intraepithelial neoplasia (CIN) [55-60]. In several cases, decreased CAT activity was associated with a reduced number of peroxisomes $[57,61]$.

2.4. Endoplasmic Reticulum. The endoplasmic reticulum (ER) has many general cellular functions, such as protein folding, synthesis, transport, and posttranslational modifications, as well as lipid metabolism and calcium storage [62]. Alterations in the folding pathway lead to accumulation of misfolded and unfolded proteins in the ER lumen resulting in ER stress. This disrupts cell homeostasis and initiates the unfolded protein response (UPR) [63, 64]. UPR triggers ROS production, and ROS, in turn, can promote ER stress $[65,66]$. In tumor cells, the UPR signaling pathway serves as an adaptive to the stress mechanism supporting their survival and propagation [67]. However, if ER stress is prolonged, the UPR triggers tumor cell apoptosis [68].

Oxidative protein folding gives rise to a highly oxidative environment in the ER lumen [69]. Protein disulfide isomerase (PDI) catalyzes thiol-disulfide exchange reactions, which form a native disulfide bond in proteins [70]. During this process, PDI is oxidized by endoplasmic reticulum oxidoreductin-1 (ERO1), which accepts electrons from a reduced $\mathrm{PDI}$ and transfers them to molecular oxygen, thereby generating $\mathrm{H}_{2} \mathrm{O}_{2}[69,71]$. ERO1 also catalyzes the conversion of glutathione $(\mathrm{GSH})$ to glutathione disulfide (GSSG), besides PDI oxidation. Accumulation of both $\mathrm{H}_{2} \mathrm{O}_{2}$ and oxidized glutathione causes ER stress. Furthermore, the ratio between GSH and GSSG is an essential marker of the redox status in the ER lumen. Moreover, GSH was proposed as a potential protection mechanism from ER-associated ROS damage [72]. PDI and ERO1 were found to be upregulated in different types of cancer and were implicated in cancer progression and metastasis. PDI and ERO1 overexpression has been found in patients with non-small cell lung cancer (NSCLC) and was significantly associated with shorter overall survival [73]. Expression of several members of the PDI family was upregulated in ovarian and colorectal cancers $[74,75]$ while ERO1 overexpression was correlated with the progression and metastasis of breast cancer, as well as with poor survival and high recurrence rates in gastric cancer [76-78]. ERO1 knockout led to the reduced growth of colorectal cancer cells under hypoxic conditions [79]. Elevated ERO1 expression was associated with poor prognosis in cervical cancer [80]. In the same study, ERO1 knockout inhibited tumor growth and migration of cervical cancer cells.

PDI is also involved in $\mathrm{H}_{2} \mathrm{O}_{2}$ generation through interconnections with NOX1 and NOX4, which belong to the nicotinamide adenine dinucleotide phosphate (NADPH) oxidase protein family $[81,82]$. In addition, NOX4 occurs in the NOX4-p22 $2^{\text {phox }}$ complex in the ER membrane and is involved in releasing $\mathrm{H}_{2} \mathrm{O}_{2}$ in the ER lumen [83]. One more site of ROS generation in the ER is the microsomal monooxygenase (MMO) system. This is a multienzyme system consisting of multiple cytochrome P450 species, NADPHP450 reductase (NPR), and cytochrome $b_{5}$ [84]. MMO catalyzes the oxygenation of hydrophobic exogenous compounds and some endogenous substrates, resulting in a production of superoxide radicals and $\mathrm{H}_{2} \mathrm{O}_{2}[85,86]$. Increased $\mathrm{MMO}$-derived ROS production and greater rates of microsomal lipid peroxidation were shown to be associated with the activation of cytochrome P450 2E1 (CYP2E1) [87, 88].

2.5. Thymidine Catabolism. Thymidine phosphorylase (TP) is a rate-limiting enzyme in thymidine catabolism that catalyzes the reversible conversion of thymidine to thymine and 2-deoxy-D-ribose-1-phosphate (DR1P) [89]. TP is upregulated in many tumors and plays an important role in angiogenesis, apoptosis evasion, invasion, and metastasis, as well as in chemotherapy response [90]. Recently, Tabata and coauthors have revealed that TP activity increases NADPH levels via the pentose phosphate pathway (PPP) which activates NADPH oxidase-dependent production of ROS in cancer cells $[6,91]$. Previously, it was shown that the addition of thymidine to a TP-overexpressing bladder carcinoma cell line induces cellular oxidative stress [92]. The authors proposed another potential mechanism of TPinduced ROS production. This mechanism is based on excess $2 \mathrm{dDR} 1 \mathrm{P}$ produced during thymidine phosphorylation that could be further subjected to transition metal-catalyzed oxidation, leading to ROS generation.

2.6. Polyamine Catabolism. The natural polyamines (PAs), putrescine, spermidine, and spermine, are involved in multiple basic cellular functions, including growth, proliferation, differentiation, apoptosis, migration, and protection from stresses. They are involved in protein posttranslational modifications, regulation of ion channels, maintenance of nucleic acid, and protein structure and stability, as well as cell-cell communications [93]. PA content and catabolism are strongly regulated at different levels by key enzymes in the biosynthesis and transport systems [94]. However, dysregulation of PA catabolism is frequently observed in cancer [95].

In mammals, putrescine is the first polyamine of the PA catabolism. It is synthesized with the participation of ornithine decarboxylase (ODC). Putrescine is further converted to higher polyamines, spermidine and spermine, a reaction catalyzed by spermidine synthase (SPDS) and spermine synthase (SPMS), respectively. S-Adenosylmethionine decarboxylase (AdoMetDC) supplies the aminopropyl groups in these reactions. The activities of ODC and AdoMetDC are considered to be a rate-limiting factors of PA biosynthesis. The other branch of PA catabolism involves the interconversion cycles where spermine is degraded to spermidine and spermidine to putrescine with the generation of toxicreactive aldehydes and ROS. Spermine oxidase (SMO) catalyzes the conversion of spermine to spermidine, which is accompanied by 3-aminopropanal and $\mathrm{H}_{2} \mathrm{O}_{2}$ release. Spermidine and spermine can also be converted to prior polyamines, with the help of spermidine/spermine-N1acetyltransferase (SSAT) and acetylpolyamine oxidase (APAO/PAOX). N-Acetyl-3-aminopropanaldehyde and $\mathrm{H}_{2} \mathrm{O}_{2}$ are produced as by-products of these reactions [94, 96]. Additionally, another degradative enzyme related to PA catabolism is a diamine oxidase (DAO) that oxidizes putrescine to $\mathrm{H}_{2} \mathrm{O}_{2}$, ammonia, and 4-aminobutanal. 
However, as putrescine is present in relatively low amounts in most mammalian tissues, this reaction does not generate significant amounts of ROS [97].

Increased PA catabolism can lead to an elevated level of ROS and oxidative stress. Overexpression of SMOX and SAT1, which encode the SMO and SSAT enzymes, respectively, was shown to be interconnected with infection, inflammation, and high risk of cancer. Several studies have reported that bacterial cytotoxins upregulate the expression of SMOX. The Helicobacter pylori virulence factor, cytotoxin-associated gene A (CagA) protein, promotes an increase in the SMOX mRNA level and enzyme activity in both human and animal gastric epithelial cells. This results in a significant increase in extra- and intracellular $\mathrm{H}_{2} \mathrm{O}_{2}$, leading to DNA damage and apoptosis, which can further contribute to inflammation and carcinogenesis [98, 99]. Using a gerbil model, it was shown that $H$. pylori infection induces overexpression of SMO and oxidative DNA damage and is associated with a high risk of gastric dysplasia and adenocarcinoma [100]. Furthermore, SMO expression was increased in gastric cancer patients infected with $H$. pylori [101]. In the same study, it was reported that activation of EGFR and ERBB2 signaling is involved in $H$. pylori-induced upregulation of SMOX.

Enterotoxigenic Bacteroides fragilis (ETBF) infection results in chronic inflammation and can promote colorectal carcinogenesis [102]. B. fragilis toxin (BFT) has also been reported to increase $S M O X$ expression leading to ROS generation and DNA damage in colonic epithelial cells [103]. A study involving patients with colorectal cancer has revealed that SMOX overexpression could be caused by the activation of the transcription factor $\mathrm{C} / \mathrm{EBP} \beta$, which is involved in the regulation of inflammation and immunity, rather than the ETBF infection [104]. The association of increased SMOX expression and chronic inflammation was also observed in several precancerous conditions such as prostatic intraepithelial neoplasia (PIN) and chronic hepatitis [105-107]. Interestingly, drug-induced modulation of polyamine catabolism in hepatic cells results in them undergoing an epithelialmesenchymal transition- (EMT-) like dedifferentiation, which is not, however, associated with elevated ROS levels [108]. This can indicate that ROS overproduction caused by increased polyamine catabolism together with chronic inflammation could be a precursor event of cancer development, but not tumor progression (with respect to metastasis).

On the contrary, an antioxidant role of polyamines has been proposed. Multiple protection mechanisms from oxidative damage with PA participation were reported: direct ROS scavenging $[109,110]$, changes in DNA structure and conformation which reduce the possibility of its interactions with reactive species $[109,111-114]$, formation of chelates with metals at low concentration which prevents ROS generation, particularly hydroxyl radicals [115], or a combination of these mechanisms. Additionally, PA metabolism was linked to $\mathrm{p} 53$-mediated ferroptosis in response to oxidative stress [116]. This mechanism is based on p53-induced SSAT activation, in the presence of high levels of ROS, leading to downstream modulation of the expression of ferroptosis components.
2.7. Oxidase Activity. Diamine oxidase (DAO) is a coppercontaining amine oxidase that catalyzes the oxidation of polyamines, such as histamine, putrescine, spermidine, and to a lesser extent spermine [97, 117]. All these reactions generate $\mathrm{H}_{2} \mathrm{O}_{2}$. DAO activity in mammals varies and was found to be tissue specific. As such, high DAO activity was found in the placenta, kidneys, lungs, small intestine, and liver $[118,119]$. Moreover, elevated DAO activity was found in prostate, breast, ovarian, cervical, and endometrial cancers [120-122] and a decrease in activity was found in colorectal cancer [123]. Increased plasma/serum DAO activity was detected in patients with endometrial, lung, and thyroid cancers [124-126]. Moreover, serum/plasma DAO activity has been proposed as an indicator of mucosal injury during chemotherapy and can be used for monitoring anticancer drug toxicity [127, 128].

Acetylpolyamine oxidase (APAO/PAOX) is related to flavin adenine dinucleotide- (FAD-) containing enzymes and catalyzes the oxidation of both spermidine and spermine in peroxisomes. Depending on the substrate, $\mathrm{N} 1$-acetylspermine or $\mathrm{N} 1$-acetylspermidine, APAO produces spermidine or putrescine, respectively, generating $\mathrm{H}_{2} \mathrm{O}_{2}$ as a by-product [129]. The presence of starting substrates of APAO is controlled by SSAT activity [130]. Induction of the SSAT/APAO pathway can increase oxidative stress; however, it seems to have a more significant contribution than the one-step spermine oxidation reaction catalyzed by SMO [131].

Spermine oxidase (SMO) is a FAD-dependent oxidase that acts directly on spermine generating spermidine, $\mathrm{H}_{2} \mathrm{O}_{2}$, and 3-aminopropanal $[132,133]$. Unlike APAO, SMO is not a peroxisomal enzyme and is located in cytoplasm or nucleus [134]. SMO activity can produce higher levels of oxidative cellular damage [135]. Elevated expression of SMOX was shown in prostate and colorectal cancers [104, 105]. Furthermore, SMOX overexpression followed by downstream oxidative damage, chronic inflammation, and carcinogenesis is often induced by infections (discussed above).

Xanthine oxidoreductase (XOR) is a molybdenum ironsulfur flavin hydroxylase that exists in two forms, xanthine dehydrogenase $(\mathrm{XDH})$ and xanthine oxidase (XOD). $\mathrm{XDH}$ can be converted to XOD either irreversibly by proteolysis or reversibly by modification of cysteine residues [136, 137]. The enzyme catalyzes the oxidation of hypoxanthine to xanthine or xanthine to uric acid during purine metabolism [138]. Both XDH and XOD generate $\mathrm{H}_{2} \mathrm{O}_{2}$ and $\mathrm{O}_{2}{ }^{\bullet-}$ through $\mathrm{NADH}$ oxidation [139]. Nevertheless, for $\mathrm{XDH}, \mathrm{NAD}+$ is a more preferable substrate compared to oxygen, and therefore, it cannot directly produce ROS [140]. XOR-released superoxide radicals rapidly react with nitric oxide $\left(\mathrm{NO}^{\bullet}\right)$ generating peroxynitrite $\left(\mathrm{ONOO}^{-}\right)$. $\mathrm{NO}^{\bullet}$, in turn, is produced by NOS activity or even by XOR under hypoxic conditions [141]. The association of XOR with neoplastic transformation was first reported many years ago [142]. Decreased XOR activity was frequently found in many animal and human tumors [143]. XOR activity was increased in meningioma, astrocytoma, and laryngeal and colorectal cancers [144-146]. This indicates that dysregulation of purine metabolism and ROS levels can play a role in tumor pathogenesis. 
Cytochrome P450 (CYP) oxidase is part of the microsomal electron transport system. It belongs to the CYP superfamily of integral membrane proteins that catalyze the oxidation of numerous organic substrates, accompanied by the reduction of molecular oxygen [147]. CYP enzymes also have peroxygenase and peroxidase activity, using $\mathrm{H}_{2} \mathrm{O}_{2}$ either for direct oxidation of substrates or as a donor of oxygen atoms [148]. The prosthetic heme group in CYP enzymes is essential for their activity [149]. $\mathrm{H}_{2} \mathrm{O}_{2}$ and superoxide radicals are produced during the CYP monooxygenase cycle; the former can be further decomposed to hydroxyl radicals $\left({ }^{\circ} \mathrm{OH}\right)$ in the presence of ferrous iron via a Fenton reaction [150]. CYP enzymes are predominantly located in the endoplasmic reticulum and mitochondria and are expressed in many mammalian tissues [151]. CYP-related ROS generation depends on CYP isoforms, content and type of substrates, $\mathrm{pH}$, ionic strength, the action of cytochrome b5, oxygen concentration, oligomerization, and so on $[150,152,153]$. Studies have shown that CYP2E1 induces higher ROS production than other CYP enzymes and that its activation or overexpression leads to increased ROS levels $[152,154]$. CYP enzyme activity can promote carcinogenesis through increased ROS production. As such, overexpression of CYP family genes was observed in many cancers [150].

The NADPH oxidase (NOX) family includes seven members: NOX1, NOX2, NOX3, NOX4, NOX5, dual oxidase 1 (DUOX1), and DUOX2 [155]. These are transmembrane proteins that transfer an electron from the NADPH substrate to $\mathrm{FAD}$ across biological membranes in order to reduce oxygen to a superoxide radical [156]. Dysregulation of NOX activity leads to elevated ROS production that can contribute to tumorigenesis, cell transformation, tumor growth, angiogenesis, and metastasis. NOX-derived ROS were shown to be implicated in many common cancer types (e.g., bladder, colorectal, breast, kidney, lung, and prostate cancers), as well as acute myeloid leukemia and non-Hodgkin's lymphoma [157-161]. Moreover, NOX family members are involved in host defense and innate immunity. NOX could be activated by various infectious agents resulting in increased ROS production which promotes the death of the infected cells as well as an inflammatory response [162]. Toll-like receptors (TLRs) located at the plasma membrane recognize conserved structures of bacteria, viruses, or fungi and trigger downstream signaling. TLRs interact with NOX, leading to increased ROS generation, as well as subsequent activation of the transcription factor NF- $\kappa \mathrm{B}$, and production of cytokines and chemokines [163-165]. Nucleotide-binding oligomerization domain- (NOD-) like receptors (NLRs) can also recognize components of the bacterial cell wall and other bacterial molecules (e.g., RNA, toxins, and ligands). NLR family members, NACHT lectin-like receptor and PYD domain-containing proteins (NLRPs), promote the assembly of inflammasomes and mediate the activation of inflammatory caspases [166]. ROS were shown to be required for the activation of NLRP3-mediated inflammasomes, and NOX, as one of the main sources of ROS production, can be involved in NLR signaling [167]. The important role of NOX-produced ROS in the NLR system was also reported by Lipinski et al. [168]. Additionally, hepatitis C virus (HCV) infection can induce NOX1 and NOX4 expression, leading to increased ROS generation in hepatocytes [169]. It was shown that HCV modulates NOX4 through TGF-beta $[169,170]$. Moreover, HCV can induce immune dysfunction via HCV nonstructural protein 3- (NS3-) induced release of ROS from phagocytes, resulting in the apoptosis of $\mathrm{T}$ lymphocytes, natural killer (NK) cells, and NKT cells $[171,172]$.

Cyclooxygenases (COX) and lipoxygenases (LOX) participate in polyunsaturated fatty acid (PUFA) metabolism, by producing bioactive eicosanoids. COX and LOX oxygenate arachidonic acid resulting in the formation of prostaglandin G2 and H2 (PGG2/PGH2) and fatty acid hydroperoxide, respectively, a reaction that is accompanied by ROS release [173]. Peroxyl radicals $\left(\mathrm{ROO}^{\circ}\right)$ and alkoxyl radicals $\left(\mathrm{RO}^{\circ}\right)$ are intermediates of the hydroperoxide metabolism. Moreover, the arachidonic acid pathway itself could be responsible for ROS generation via NADPH oxidase activation [174]. In spite of the similarity between COX/LOX-catalyzing reactions, they have a completely different sequence, structure, cellular localization, and tissue expression [175]. COX is present in three isoforms - constitutive (COX-1), inducible (COX-2), and splice variant of COX-1 (COX-3) [176]. The PTGS1 gene encodes for both COX-1 and COX-3 isoenzymes; however, COX-3 activity in humans remains unclear [177, 178]. PTGS2 encodes for COX-2. COX-1 predominantly regulates basal prostaglandin metabolism and normal tissue homeostasis [179]. COX-2 is induced by proinflammatory stimuli, cytokines, and growth factors in response to inflammation, tissue injury, and tumorigenesis $[180,181]$. COX-2 overexpression and increased prostaglandin biosynthesis have been found in both the precancer stages and various tumors [173, 182-184]. COX1 was upregulated in breast, cervical, ovarian, endometrial, and colorectal cancers, as well as in cholangiocarcinoma [185-190].

LOX constitutes a large family of nonheme ironcontaining dioxygenases; five LOX isoenzymes were found in humans (5-LOX, 12-LOX, 12R-LOX, two 15-LOX, and 3-LOX/E-LOX). Dysregulated LOX expression was observed in various tumors and animal models. A dual role of LOX in tumorigenesis has been proposed, as they can be involved in both neoplastic transformation and tumor suppression [173].

Monoamine oxidases A and B (MAOA and MAOB) are mitochondrial FAD-dependent enzymes encoded by separate genes [191, 192]. They catalyze the oxidative deamination of monoamines, including monoamine neurotransmitters (e.g., norepinephrine, dopamine, serotonin, and epinephrine), exogenous dietary amines, and drugs, generating $\mathrm{H}_{2} \mathrm{O}_{2}$ and aldehydes as by-products $[193,194]$. Excessive MAO activity leads to enhanced ROS production and mitochondrial damage and is implicated in aging, cardiovascular diseases, neurodegenerative disorders, and cancer [195-197]. Increased MAOA expression was found in lung, prostate, and breast cancers, as well as hepatocellular carcinoma and cholangiocarcinoma [198-203]. Moreover, several studies suggested that MAOA can promote cancer progression through induction of EMT [197, 198]. Conversely, MAOA was downregulated in a number of cancer tissues 
and significantly differed between them [204]. In this case, the potential mechanism of tumor progression can be related to an increase in the amounts of MAOA substrate epinephrine $[205,206]$.

Lysyl oxidase is a family of copper-dependent enzymes that play a primary role in the remodeling of the extracellular matrix (ECM). They catalyze the conversion of specific lysine residues into reactive aldehyde groups in collagen and elastin, forming protein crosslinks [207]. The lysyl oxidase catalytic cycle also produces $\mathrm{H}_{2} \mathrm{O}_{2}$, which can increase oxidative stress thereby promoting carcinogenesis. Overexpression of lysyl oxidase and its involvement in tumor progression and metastasis were shown in various cancers [208-214].

2.8. Signaling Pathways. The PI3K/AKT/PTEN signaling pathway is implicated in NOX-derived ROS production [215]. PTEN (phosphatase and tensin homolog) is a tumor suppressor responsible for the negative regulation of PI3K/AKT signaling. Loss of PTEN expression or mutations in the gene, as well as dysregulation of the PI3K/AKT signaling pathway, were frequently found in many tumors $[216,217]$.

NOXs are multimeric enzymes consisting of several proteins that are distributed between the membrane and cytosol when inactive. Upon activation by different stimuli, the cytosolic subunits interact with integral membrane subunits, forming the functional NOX enzymes which can generate ROS [218]. It was shown that PI3K/AKT inhibitors can reduce NOX-dependent ROS generation through the inhibition of NOX subunit translocation into the membrane. In addition, membrane depolarization with downstream PI3K/AKT and (protein kinase C) PKC activation causes NOX assembly and ROS production [215]. Moreover, oxidative stress inhibits PTEN-induced PI3K/AKT signaling, which promotes both the expression of cell survival genes and ROS production [219]. Such mechanisms may contribute to tumor cell proliferation and growth under oxidative conditions. Several other enzymes, including PKC, mitogenactivated protein kinases (MAPK), cAMP-dependent protein kinases (PKA), p21-activated kinases (PAK), and PKB/AKT, can modulate the activation of NOXs through phosphorylation of their cytosolic subunits, thereby increasing the level of ROS [220]. All the aforementioned enzymes were shown to be greatly involved in cancer development [221-223].

Transcription factor p53 is a widely known tumor suppressor, involved in regulating the expression of various genes encoding for both ROS-producing and antioxidantrelated components [224]. p53 induces the expression of glutathione peroxidase 1 (GPX1) and mitochondrial superoxide dismutase 2 , both components of the key antioxidant defense system [225, 226]. Moreover, p53 regulates the expression of sestrins (SESN1 and SESN2) that are required for peroxiredoxins regeneration [227]. Phosphate-activated mitochondrial glutaminase (GLS2) converts glutamine to glutamate, which is a precursor for glutathione synthesis. GLS2 expression can be induced by p53 in response to DNA damage or oxidative stress to promote antioxidant defense by controlling the GSH/GSSG ratio [228]. Other p53-inducible antioxidant genes are TIGAR and ALDH4. TIGAR negatively regulates glycolysis and decreases intracel- lular ROS levels [229], while aldehyde dehydrogenase 4 (ALDH4) is a NAD+-dependent enzyme that catalyzes the second step of the proline degradation pathway in the mitochondrial matrix [230]. Overexpression of ALDH4 in p53-null cells inhibits ROS generation and apoptosis [231].

The function of prooxidant p53 is based on its ability to regulate the expression of genes encoding for prooxidant enzymes, such as PUMA (the p53-upregulated modulator of apoptosis), p66Shc (66 kDa Src collagen homologue (Shc) adaptor protein), and other proteins encoded by a group of p53-induced genes (PIGs). PUMA overexpression induces $\mathrm{BCL} 2$-associated $\mathrm{X}(\mathrm{BAX})$ protein-dependent ROS generation (predominantly superoxide radicals and $\mathrm{H}_{2} \mathrm{O}_{2}$ ) and apoptosis in colorectal cancer cells [232]. p66Shc generates mitochondrial $\mathrm{H}_{2} \mathrm{O}_{2}$ as signaling molecules for the induction of apoptosis [233]. PIG is a family of proteins, whose several members were shown to influence the cell redox status. P53-induced activation of PIGs results in increased ROS levels and mitochondria-derived apoptosis in colorectal cancer cells [234]. It was shown that p53 promotes the expression of PIG3, BAX, and PUMA leading to an increase in intracellular ROS levels and induction of apoptosis. Moreover, the authors have demonstrated that p53 induction is associated with the excessive ROS release by mitochondria, which supports its prooxidant role [235].

\section{Role of Glycolysis and the Pentose Phosphate Pathway in Antioxidant Defense}

Glycolysis and the pentose phosphate pathway are involved in ROS detoxification. Glycolysis occurs in living cells both in anaerobic and aerobic conditions. Aerobic glycolysis generates pyruvate that is converted to acetyl-CoA with the release of carbon dioxide in the mitochondrial tricarboxylic acid (TCA) cycle, while in the absence of oxygen, lactate is produced [236]. Most tumor cells use anaerobic glycolysis even in the presence of oxygen; this phenomenon is termed the "Warburg effect" [237]. Glycolysis reprogramming allows tumor cells to redirect this process to support de novo nucleotide synthesis during proliferation [238]. Dysregulation in the expression of genes encoding for key glycolytic components has been found in many tumors [239-246]. Increased glycolysis in tumor cells can reduce ROS production via a decrease in OXPHOS activity [247].

The NADPH/NADP+ ratio is important for antioxidant defense; NADPH acts as a donor of reductive potential to glutathione and thioredoxin reductases. The main source of $\mathrm{NADPH}$ is the oxidative branch of the pentose phosphate pathway (ox-PPP) [248]. Glucose-6-phosphate (G6P) derived from glucose phosphorylation by hexokinases (HKs) is reduced to 6-phosphogluconate and NADPH via glucose-6-phosphate dehydrogenase (G6PD) during the first step of ox-PPP. In the next step, 6-phosphogluconate dehydrogenase (6PG) catalyzes the oxidative decarboxylation of 6-phosphogluconate to ribulose-5-phosphate (Ru5P) providing the additional NADPH [249]. The NADP+/NADPH ratio regulates $\mathrm{G} 6 \mathrm{PD}$ and $6 \mathrm{PG}$ activity in order to produce more NADPH for oxidative stress prevention [250]. Several glycolytic enzymes, such as phosphofructokinase-1 (PFK1), 
TABLE 1: ROS and major mechanisms of their generation and detoxification.

\begin{tabular}{|c|c|c|}
\hline ROS & Generation & Detoxification \\
\hline Superoxide radical $\left(\mathrm{O}_{2}{ }^{\bullet-}\right)$ & $\begin{array}{c}\text { Mitochondrial respiratory chain } \\
\text { Electron transport chain in the peroxisomal } \\
\text { membrane } \\
\text { Superoxide dismutases } \\
\text { CYP catalytic cycle } \\
\text { Mitochondrial enzymes (glycerol 3-phosphate } \\
\text { dehydrogenase, 2-oxoglutarate dehydrogenase, } \\
\text { NADH-cytochrome b5 reductase, etc.) } \\
\text { Xanthine oxidoreductase }\end{array}$ & $\begin{array}{l}\text { Superoxide dismutases } \\
\text { Polyamines }\end{array}$ \\
\hline Hydrogen peroxide $\left(\mathrm{H}_{2} \mathrm{O}_{2}\right)$ & $\begin{array}{c}\text { Spontaneous dismutation of superoxide radicals } \\
\text { Polyamine catabolism } \\
\text { Thymidine catabolism } \\
\text { NADPH oxidases } \\
\text { Monoamine oxidases } \\
\text { Lysyl oxidases } \\
\text { Dihydroorotate dehydrogenase } \\
\text { CYP catalytic cycle } \\
\text { Peroxisomal enzymes (acyl-CoA oxidases, } \\
\text { d-amino acid oxidase, d-aspartate oxidase, etc.) } \\
\text { Microsomal monooxygenase (MMO) system } \\
\text { Normal protein folding/unfolded protein response } \\
\text { Polyunsaturated fatty acid metabolism }\end{array}$ & $\begin{array}{c}\text { Polyamines } \\
\text { Glutathione peroxidases } \\
\text { Thioredoxin peroxidases } \\
\text { Catalase } \\
\text { Peroxiredoxins } \\
\text { Glutathione S-transferases } \\
\text { Glutaredoxins } \\
\text { Thioredoxins } \\
\text { Nonenzymatic scavengers* } \\
\text { Glycolysis } \\
\text { Pentose phosphate pathway }\end{array}$ \\
\hline Hydroxyl radical $\left({ }^{\bullet} \mathrm{OH}\right)$ & $\begin{array}{l}\text { Fenton and Haber-Weiss reactions } \\
\text { Thymidine catabolism (supposed) } \\
\text { Aconitase via Fenton reaction }\end{array}$ & $\begin{array}{c}\text {-OH has a very short half-life and is very rapidly } \\
\text { involved in other reactions } \\
\text { Polyamines }\end{array}$ \\
\hline Singlet oxygen $\left(\mathrm{O}_{2}\right)$ & $\begin{array}{c}\text { Nonphotosensitized mechanisms of } \mathrm{O}_{2} \\
\text { generation** }\end{array}$ & $\begin{array}{c}\mathrm{O}_{2} \text { is rapidly implicated in many oxidation } \\
\text { reactions } \\
\text { Polyamines }\end{array}$ \\
\hline Hydroperoxyl radical (HOO $\left.{ }^{\bullet}\right)$ & Protonated form of $\mathrm{O}_{2}{ }^{--}$ & Nonenzymatic scavengers \\
\hline Peroxyl radical $\left(\mathrm{ROO}^{\bullet}\right)$ & Polyunsaturated fatty acid metabolism & Nonenzymatic scavengers \\
\hline Alkoxyl radical $\left(\mathrm{RO}^{\bullet}\right)$ & Polyunsaturated fatty acid metabolism & Nonenzymatic scavengers \\
\hline
\end{tabular}

glyceraldehyde 3-phosphate dehydrogenase (GAPDH), and pyruvate kinase (PK), as well as the TP53-inducible glycolysis and apoptosis regulator (TIGAR), are involved in the redirection of glycolytic flux through the ox-PPP in order to reduce the ROS level [251]. Moreover, the acceleration of glycolysis and PPP in a tumor cell can protect it from oxidative damage [252].

\section{Tumor Microenvironment}

Solid tumors are commonly infiltrated with different types of cells, including cancer-associated fibroblasts (CAFs), immune cells, pericytes, adipocytes, and other tissueassociated cells. This forms a distinct tumor microenvironment that comprises cell-cell and cell-extracellular matrix interactions, as well as many soluble factors $[253,254]$. The latter include vascular endothelial growth factors (VEGFs), fibroblast growth factors (FGFs), angiopoietins (ANGs), transforming growth factors (TNFs), ROS, chemokines, cytokines, exosomes, microRNAs, $\mathrm{Ca}^{2+}, \mathrm{K}^{+}, \mathrm{Na}^{+}, \mathrm{H}^{+}$, and other ions [255-257]. The tumor microenvironment plays an essential role in tumor initiation, progression, and metastasis [258]. It is also involved in the resistance to targeted therapy, radiation, and chemotherapy, as well as sensitivity to immunotherapy $[259,260]$.

Relatively stable ROS, such as $\mathrm{H}_{2} \mathrm{O}_{2}$, which is produced at a high level by tumor cells, can diffuse into the extracellular space. $\mathrm{H}_{2} \mathrm{O}_{2}$ can freely cross membranes; however, the cells seem to regulate $\mathrm{H}_{2} \mathrm{O}_{2}$ transport by changes in membrane lipid composition, thereby maintaining cellular $\mathrm{H}_{2} \mathrm{O}_{2}$ concentration [261]. Aquaporins (AQPs) have also been found to be transporters of $\mathrm{H}_{2} \mathrm{O}_{2}[262,263]$. Moreover, superoxide dismutase 3 (SOD3, EC-SOD) and NADPH oxidase provide extracellular ROS sources. SOD3, which is located in the extracellular space, catalyzes the dismutation of the superoxide anion into $\mathrm{H}_{2} \mathrm{O}_{2}$ [264], while several NOX isoforms generate $\mathrm{H}_{2} \mathrm{O}_{2}$ and $\mathrm{O}_{2}{ }^{\bullet-}$ outside cells $[156,265]$. Extracellular ROS signaling in tumor cells with the participation of SOD and NOX enzymes has been well described by Bauer et al. [266]. Briefly, NOX located in the plasma membrane produces $\mathrm{O}_{2}{ }^{--}$into the extracellular space. The superoxide radical, in turn, dismutates to $\mathrm{H}_{2} \mathrm{O}_{2}$ during the hypochlorous 


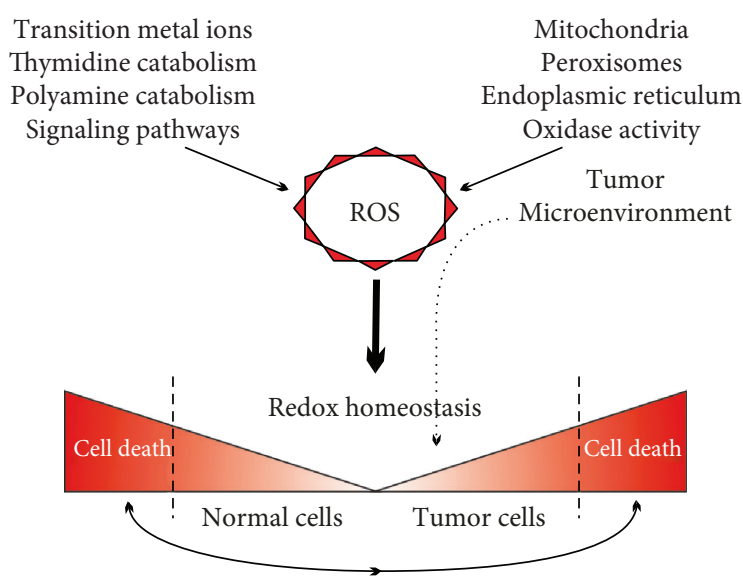

FIGURE 1: Main sources of ROS production in normal and tumor cells.

acid (HOCl) pathway. Peroxidases (POD) use the $\mathrm{H}_{2} \mathrm{O}_{2}$ as a substrate to generate $\mathrm{HOCl}$, which further reacts with hydroxyl anions $\left(\mathrm{OH}^{-}\right)$leading to the formation of hydroxyl radicals $\left({ }^{\circ} \mathrm{OH}\right)$. NOX-generated $\mathrm{O}_{2}{ }^{\cdot-}$ is reduced to $\mathrm{H}_{2} \mathrm{O}_{2}$ either by SOD3 or spontaneously; membrane CAT decomposes the produced $\mathrm{H}_{2} \mathrm{O}_{2}$ thereby inhibiting $\mathrm{HOCl}$ signaling. CAT can also decompose peroxynitrite $\left(\mathrm{ONOO}^{-}\right)$derived from the reaction between $\mathrm{NO}$ and $\mathrm{H}_{2} \mathrm{O}_{2}$ that prevents hydroxyl radical formation through the $\mathrm{NO}$ /peroxynitrite pathway.

Apart from tumor cells, cancer-associated fibroblasts also release extracellular $\mathrm{H}_{2} \mathrm{O}_{2}$ that induces oxidative stress in normal fibroblasts, triggering their reprogramming to CAFs and promoting field cancerization, epithelial cell transformation and growth, and cancer aggressiveness [267]. Immune cells, such as myeloid-derived suppressor cells (MDSCs), tumor-associated macrophages (TAMs), regulatory $\mathrm{T}$ cells (Tregs), neutrophils, eosinophils, and mononuclear phagocytes, can also generate ROS (mainly $\mathrm{H}_{2} \mathrm{O}_{2}$ ) into the tumor microenvironment $[253,268]$.

The major mechanisms of ROS generation and detoxification are presented in Table 1 and Figure 1.

\section{Conclusions}

ROS are generated by multiple cellular processes and can be overproduced in response to different stimuli. Normal cells can maintain oxidative homeostasis owing to the activity of various antioxidant systems which control ROS production through changes in metabolic and signaling pathways. Upon a permanent increase in ROS levels, the antioxidant defense mechanisms can promote cell death. However, oxidative stress damages many molecules, cell structures, and functions leading to the development of pathological states, such as inflammation, aging, neurodegenerative disorders, and cancer. ROS are greatly implicated in tumorigenesis, and summarizing the current data on ROS biology is important for understanding the mechanisms of tumor initiation, promotion, and progression, as well as for treatment development.

\section{Conflicts of Interest}

The authors declare that there is no conflict of interest regarding the publication of this paper.

\section{Acknowledgments}

This work and publication costs were financially supported by the Russian Science Foundation, grants 17-75-20105 (review of mitochondrial dysfunction and alterations in metabolic and signaling pathways as the important ROS sources) and 17-74-20064 (review of ROS generation and detoxification mechanisms frequently dysregulated in cancer). This work was performed using the equipment of the Genome Center of the Engelhardt Institute of Molecular Biology (http://www.eimb.ru/rus/ckp/ccu_genome_c.php).

\section{References}

[1] J. Zhang, X. Wang, V. Vikash et al., "ROS and ROS-mediated cellular signaling," Oxidative Medicine and Cellular Longevity, vol. 2016, Article ID 4350965, 18 pages, 2016.

[2] A. A. Alfadda and R. M. Sallam, "Reactive oxygen species in health and disease," Journal of Biomedicine and Biotechnology, vol. 2012, Article ID 936486, 14 pages, 2012.

[3] A. V. Kudryavtseva, G. S. Krasnov, A. A. Dmitriev et al., "Mitochondrial dysfunction and oxidative stress in aging and cancer," Oncotarget, vol. 7, no. 29, pp. 44879-44905, 2016.

[4] P. Storz, "Reactive oxygen species in tumor progression," Frontiers in Bioscience, vol. 10, no. 1-3, pp. 1881-1896, 2005.

[5] T. B. Dansen and K. W. Wirtz, "The peroxisome in oxidative stress,” IUBMB Life, vol. 51, no. 4, pp. 223-230, 2001.

[6] S. Tabata, R. Ikeda, M. Yamamoto et al., "Thymidine phosphorylase enhances reactive oxygen species generation and interleukin-8 expression in human cancer cells," Oncology Reports, vol. 28, no. 3, pp. 895-902, 2012.

[7] R. Amendola, M. Cervelli, G. Tempera et al., "Spermine metabolism and radiation-derived reactive oxygen species for future therapeutic implications in cancer: an additive or adaptive response," Amino Acids, vol. 46, no. 3, pp. 487-498, 2014.

[8] S. Kumari, A. K. Badana, G. Murali Mohan, G. Shailender, and R. R. Malla, "Reactive oxygen species: a key constituent in cancer survival," Biomarker Insights, vol. 13, article $1177271918755391,2018$.

[9] S. Galadari, A. Rahman, S. Pallichankandy, and F. Thayyullathil, "Reactive oxygen species and cancer paradox: to promote or to suppress?," Free Radical Biology \& Medicine, vol. 104, pp. 144-164, 2017.

[10] M. D. Brand, "The sites and topology of mitochondrial superoxide production," Experimental Gerontology, vol. 45, no. 7-8, pp. 466-472, 2010.

[11] A. Okado-Matsumoto and I. Fridovich, "Subcellular distribution of superoxide dismutases (SOD) in rat liver: $\mathrm{Cu}, \mathrm{Zn}-\mathrm{SOD}$ in mitochondria," Journal of Biological Chemistry, vol. 276, no. 42 , pp. 38388-38393, 2001.

[12] J. Vasquez-Vivar, B. Kalyanaraman, and M. C. Kennedy, "Mitochondrial aconitase is a source of hydroxyl radical. An electron spin resonance investigation," Journal of Biological Chemistry, vol. 275, no. 19, pp. 14064-14069, 2000. 
[13] H. Yasui, S. Hayashi, and H. Sakurai, "Possible involvement of singlet oxygen species as multiple oxidants in p450 catalytic reactions," Drug Metabolism and Pharmacokinetics, vol. 20, no. 1, pp. 1-13, 2005.

[14] T. Omura, "Mitochondrial P450s," Chemico-Biological Interactions, vol. 163, no. 1-2, pp. 86-93, 2006.

[15] S. A. Whatley, D. Curti, F. D. Gupta et al., "Superoxide, neuroleptics and the ubiquinone and cytochrome $b_{5}$ reductases in brain and lymphocytes from normals and schizophrenic patients," Molecular Psychiatry, vol. 3, no. 3, pp. 227-237, 1998.

[16] H. J. Forman and J. Kennedy, "Dihydroorotate-dependent superoxide production in rat brain and liver. A function of the primary dehydrogenase," Archives of Biochemistry and Biophysics, vol. 173, no. 1, pp. 219-224, 1976.

[17] M. Hey-Mogensen, R. L. S. Goncalves, A. L. Orr, and M. D. Brand, "Production of superoxide $/ \mathrm{H}_{2} \mathrm{O}_{2}$ by dihydroorotate dehydrogenase in rat skeletal muscle mitochondria," Free Radical Biology \& Medicine, vol. 72, pp. 149-155, 2014.

[18] L. Zhang, L. Yu, and C. A. Yu, "Generation of superoxide anion by succinate-cytochromec reductase from bovine heart mitochondria," Journal of Biological Chemistry, vol. 273, no. 51, pp. 33972-33976, 1998.

[19] N. Kaludercic, J. Mialet-Perez, N. Paolocci, A. Parini, and F. Di Lisa, "Monoamine oxidases as sources of oxidants in the heart," Journal of Molecular and Cellular Cardiology, vol. 73, pp. 34-42, 2014.

[20] T. Rabilloud, M. Heller, M. P. Rigobello, A. Bindoli, R. Aebersold, and J. Lunardi, "The mitochondrial antioxidant defence system and its response to oxidative stress," Proteomics, vol. 1, no. 8, pp. 1105-1110, 2001.

[21] I. Hanukoglu, “Antioxidant protective mechanisms against reactive oxygen species (ROS) generated by mitochondrial P450 systems in steroidogenic cells," Drug Metabolism Reviews, vol. 38, no. 1-2, pp. 171-196, 2006.

[22] M. Mari, A. Morales, A. Colell, C. Garcia-Ruiz, and J. C. Fernandez-Checa, "Mitochondrial glutathione, a key survival antioxidant," Antioxidants \& Redox Signaling, vol. 11, no. 11, pp. 2685-2700, 2009.

[23] Y. Orii, "The cytochrome c peroxidase activity of cytochrome oxidase," Journal of Biological Chemistry, vol. 257, no. 16, pp. 9246-9248, 1982.

[24] R. E. Beyer, "The participation of coenzyme Q in free radical production and antioxidation," Free Radical Biology \& Medicine, vol. 8, no. 6, pp. 545-565, 1990.

[25] M. R. Fernando, J. M. Lechner, S. Lofgren, V. N. Gladyshev, and M. F. Lou, "Mitochondrial thioltransferase (glutaredoxin 2) has GSH-dependent and thioredoxin reductase-dependent peroxidase activities in vitro and in lens epithelial cells," The FASEB Journal, vol. 20, no. 14, pp. 2645-2647, 2006.

[26] A.-J. L. Ham and D. C. Liebler, "Vitamin E oxidation in rat liver mitochondria," Biochemistry, vol. 34, no. 17, pp. 5754-5761, 1995.

[27] R. Radi, J. F. Turrens, L. Y. Chang, K. M. Bush, J. D. Crapo, and B. A. Freeman, "Detection of catalase in rat heart mitochondria," Journal of Biological Chemistry, vol. 266, no. 32, pp. 22028-22034, 1991.

[28] C. D. Phung, J. A. Ezieme, and J. F. Turrens, "Hydrogen peroxide metabolism in skeletal muscle mitochondria," Archives of Biochemistry and Biophysics, vol. 315, no. 2, pp. 479-482, 1994.
[29] I. G. Kirkinezos and C. T. Moraes, "Reactive oxygen species and mitochondrial diseases," Seminars in Cell \& Developmental Biology, vol. 12, no. 6, pp. 449-457, 2001.

[30] A. Rimessi, M. Previati, F. Nigro, M. R. Wieckowski, and P. Pinton, "Mitochondrial reactive oxygen species and inflammation: molecular mechanisms, diseases and promising therapies," The International Journal of Biochemistry \& Cell Biology, vol. 81, Part B, pp. 281-293, 2016.

[31] P. Newsholme, E. P. Haber, S. M. Hirabara et al., "Diabetes associated cell stress and dysfunction: role of mitochondrial and non-mitochondrial ROS production and activity," The Journal of Physiology, vol. 583, no. 1, pp. 9-24, 2007.

[32] A. van der Vliet, Y. M. W. Janssen-Heininger, and V. Anathy, "Oxidative stress in chronic lung disease: from mitochondrial dysfunction to dysregulated redox signaling," Molecular Aspects of Medicine, vol. 63, pp. 59-69, 2018.

[33] K. Księżakowska-Łakoma, M. Żyła, and J. R. Wilczyński, "Mitochondrial dysfunction in cancer," Przeglad Menopauzalny = Menopause review, vol. 2, no. 2, pp. 136-144, 2014.

[34] Z. Zou, H. Chang, H. Li, and S. Wang, "Induction of reactive oxygen species: an emerging approach for cancer therapy," Apoptosis, vol. 22, no. 11, pp. 1321-1335, 2017.

[35] D. Beyersmann and A. Hartwig, "Carcinogenic metal compounds: recent insight into molecular and cellular mechanisms," Archives of Toxicology, vol. 82, no. 8, pp. 493-512, 2008.

[36] M. Valko, K. Jomova, C. J. Rhodes, K. Kuca, and K. Musilek, "Redox- and non-redox-metal-induced formation of free radicals and their role in human disease," Archives of Toxicology, vol. 90, no. 1, pp. 1-37, 2016.

[37] S. I. Liochev and I. Fridovich, "The Haber-Weiss cycle-70 years later: an alternative view," Redox Report, vol. 7, no. 1, pp. 55-57, 2002.

[38] A. Valavanidis, T. Vlachogianni, and C. Fiotakis, "8-Hydroxy-2' -deoxyguanosine (8-OHdG): a critical biomarker of oxidative stress and carcinogenesis," Journal of Environmental Science and Health Part C: Environmental Carcinogenesis \& Ecotoxicology Reviews, vol. 27, no. 2, pp. 120-139, 2009.

[39] L. A. Del Río and E. López-Huertas, "ROS generation in peroxisomes and its role in cell signaling," Plant and Cell Physiology, vol. 57, no. 7, pp. 1364-1376, 2016.

[40] I. Singh, "Biochemistry of peroxisomes in health and disease," Molecular and Cellular Biochemistry, vol. 167, no. 1-2, pp. 1-29, 1997.

[41] S. Di Meo, T. T. Reed, P. Venditti, and V. M. Victor, "Role of ROS and RNS sources in physiological and pathological conditions," Oxidative Medicine and Cellular Longevity, vol. 2016, Article ID 1245049, 44 pages, 2016.

[42] C. De Duve and P. Baudhuin, "Peroxisomes (microbodies and related particles)," Physiological Reviews, vol. 46, no. 2, pp. 323-357, 1966.

[43] R. Fritz, J. Bol, U. Hebling et al., "Compartment-dependent management of $\mathrm{H}_{2} \mathrm{O}_{2}$ by peroxisomes," Free Radical Biology \& Medicine, vol. 42, no. 7, pp. 1119-1129, 2007.

[44] A. Boveris, N. Oshino, and B. Chance, "The cellular production of hydrogen peroxide," Biochemical Journal, vol. 128, no. 3, pp. 617-630, 1972.

[45] M. Fransen, M. Nordgren, B. Wang, and O. Apanasets, "Role of peroxisomes in ROS/RNS-metabolism: implications for 
human disease," Biochimica et Biophysica Acta (BBA) Molecular Basis of Disease, vol. 1822, no. 9, pp. 1363-1373, 2012.

[46] M. Valko, H. Morris, and M. T. Cronin, "Metals, toxicity and oxidative stress," Current Medicinal Chemistry, vol. 12, no. 10, pp. 1161-1208, 2005.

[47] J. M. C. Gutteridge and B. Halliwell, "Comments on review of free radicals in biology and medicine, second edition, by Barry Halliwell and John M. C. Gutteridge," Free Radical Biology \& Medicine, vol. 12, no. 1, pp. 93-94, 1992.

[48] L. M. Sandalio, V. M. Fernandez, F. L. Ruperez, and L. A. Del Rio, "Superoxide free radicals are produced in glyoxysomes," Plant Physiology, vol. 87, no. 1, pp. 1-4, 1988.

[49] N. Usuda, M. K. Reddy, T. Hashimoto, M. S. Rao, and J. K. Reddy, "Tissue specificity and species differences in the distribution of urate oxidase in peroxisomes," Laboratory Investigation, vol. 58, no. 1, pp. 100-111, 1988.

[50] L. M. Sandalio, M. Rodriguez-Serrano, M. C. RomeroPuertas, and L. A. del Rio, "Role of peroxisomes as a source of reactive oxygen species (ROS) signaling molecules," Sub-cellular Biochemistry, vol. 69, pp. 231-255, 2013.

[51] R. Harrison, "Structure and function of xanthine oxidoreductase: where are we now?," Free Radical Biology \& Medicine, vol. 33, no. 6, pp. 774-797, 2002.

[52] L. A. Del Rio, "Peroxisomes as a cellular source of reactive nitrogen species signal molecules," Archives of Biochemistry and Biophysics, vol. 506, no. 1, pp. 1-11, 2011.

[53] P. Pacher, J. S. Beckman, and L. Liaudet, "Nitric oxide and peroxynitrite in health and disease," Physiological Reviews, vol. 87, no. 1, pp. 315-424, 2007.

[54] E. Panieri and M. M. Santoro, "ROS homeostasis and metabolism: a dangerous liason in cancer cells," Cell Death ఓ Disease, vol. 7, no. 6, article e2253, 2016.

[55] C. Lauer, A. Volkl, S. Riedl, H. D. Fahimi, and K. Beier, "Impairment of peroxisomal biogenesis in human colon carcinoma," Carcinogenesis, vol. 20, no. 6, pp. 985-989, 1999.

[56] J. Chung-man Ho, S. Zheng, S. A. Comhair, C. Farver, and S. C. Erzurum, "Differential expression of manganese superoxide dismutase and catalase in lung cancer," Cancer Research, vol. 61, no. 23, pp. 8578-8585, 2001.

[57] W. M. Frederiks, K. S. Bosch, K. A. Hoeben, J. van Marle, and S. Langbein, "Renal cell carcinoma and oxidative stress: the lack of peroxisomes," Acta Histochemica, vol. 112, no. 4, pp. 364-371, 2010.

[58] D. G. Bostwick, E. E. Alexander, R. Singh et al., “Antioxidant enzyme expression and reactive oxygen species damage in prostatic intraepithelial neoplasia and cancer," Cancer, vol. 89, no. 1, pp. 123-134, 2000.

[59] M. Y. Cho, J. Y. Cheong, W. Lim et al., "Prognostic significance of catalase expression and its regulatory effects on hepatitis B virus $\mathrm{X}$ protein $(\mathrm{HBx})$ in $\mathrm{HBV}$-related advanced hepatocellular carcinomas," Oncotarget, vol. 5, no. 23, pp. 12233-12246, 2014.

[60] I. Vuillaume, Y. Decroix, R. Calvayrac et al., "Catalaseassociated abnormalities and $\mathrm{H}_{2} \mathrm{O}_{2}$ increase in preneoplastic and neoplastic lesions of the human lower female genital tract and their near adjacent epithelia," Biomedicine \& Pharmacotherapy, vol. 45, no. 10, pp. 435-444, 1991.
[61] J. A. Litwin, K. Beier, A. Volkl, W. J. Hofmann, and H. D. Fahimi, "Immunocytochemical investigation of catalase and peroxisomal lipid $\beta$-oxidation enzymes in human hepatocellular tumors and liver cirrhosis," Virchows Archiv, vol. 435, no. 5, pp. 486-495, 1999.

[62] D. S. Schwarz and M. D. Blower, "The endoplasmic reticulum: structure, function and response to cellular signaling," Cellular and Molecular Life Sciences, vol. 73, no. 1, pp. 79-94, 2016.

[63] M. Schroder and R. J. Kaufman, "ER stress and the unfolded protein response," Mutation Research, vol. 569, no. 1-2, pp. 29-63, 2005.

[64] P. Scriven, N. J. Brown, A. G. Pockley, and L. Wyld, "The unfolded protein response and cancer: a brighter future unfolding?," Journal of Molecular Medicine, vol. 85, no. 4, pp. 331-341, 2007.

[65] C. X. C. Santos, L. Y. Tanaka, J. Wosniak Jr., and F. R. M. Laurindo, "Mechanisms and implications of reactive oxygen species generation during the unfolded protein response: roles of endoplasmic reticulum oxidoreductases, mitochondrial electron transport, and NADPH oxidase," Antioxidants \& Redox Signaling, vol. 11, no. 10, pp. 2409-2427, 2009.

[66] W. S. Wu, "The signaling mechanism of ROS in tumor progression," Cancer and Metastasis Reviews, vol. 25, no. 4, pp. 695-705, 2007.

[67] A. Papaioannou and E. Chevet, "Driving cancer tumorigenesis and metastasis through UPR signaling," Current Topics in Microbiology and Immunology, vol. 414, pp. 159-192, 2018.

[68] H. J. Clarke, J. E. Chambers, E. Liniker, and S. J. Marciniak, "Endoplasmic reticulum stress in malignancy," Cancer Cell, vol. 25, no. 5, pp. 563-573, 2014.

[69] B. P. Tu and J. S. Weissman, "Oxidative protein folding in eukaryotes: mechanisms and consequences," The Journal of Cell Biology, vol. 164, no. 3, pp. 341-346, 2004.

[70] L. Ellgaard and L. W. Ruddock, "The human protein disulphide isomerase family: substrate interactions and functional properties," EMBO Reports, vol. 6, no. 1, pp. 28-32, 2005.

[71] E. Zito, "ERO1: a protein disulfide oxidase and $\mathrm{H}_{2} \mathrm{O}_{2}$ producer," Free Radical Biology \& Medicine, vol. 83, pp. 299-304, 2015.

[72] H. M. Zeeshan, G. H. Lee, H. R. Kim, and H. J. Chae, "Endoplasmic reticulum stress and associated ROS," International Journal of Molecular Sciences, vol. 17, no. 3, p. 327, 2016.

[73] K. M. Kim, A. R. An, H. S. Park et al., "Combined expression of protein disulfide isomerase and endoplasmic reticulum oxidoreductin 1- $\alpha$ is a poor prognostic marker for nonsmall cell lung cancer," Oncology Letters, vol. 16, no. 5, pp. 5753-5760, 2018.

[74] S. Samanta, S. Tamura, L. Dubeau et al., "Expression of protein disulfide isomerase family members correlates with tumor progression and patient survival in ovarian cancer," Oncotarget, vol. 8, no. 61, pp. 103543-103556, 2017.

[75] Z. Yang, J. Liu, Q. Shi et al., "Expression of protein disulfide isomerase A3 precursor in colorectal cancer," OncoTargets and Therapy, vol. 11, pp. 4159-4166, 2018.

[76] G. Kutomi, Y. Tamura, T. Tanaka et al., "Human endoplasmic reticulum oxidoreductin 1- $\alpha$ is a novel predictor for poor prognosis of breast cancer," Cancer Science, vol. 104, no. 8, pp. 1091-1096, 2013. 
[77] S. Y. Seol, C. Kim, J. Y. Lim et al., "Overexpression of endoplasmic reticulum oxidoreductin $1-\alpha$ (ERO1L) is associated with poor prognosis of gastric cancer," Cancer Research and Treatment, vol. 48, no. 4, pp. 1196-1209, 2016.

[78] B. Zhou, G. Wang, S. Gao et al., "Expression of ERO1L in gastric cancer and its association with patient prognosis," Experimental and Therapeutic Medicine, vol. 14, no. 3, pp. 2298-2302, 2017.

[79] N. Takei, A. Yoneda, K. Sakai-Sawada, M. Kosaka, K. Minomi, and Y. Tamura, "Hypoxia-inducible ERO1 $\alpha$ promotes cancer progression through modulation of integrin- $\beta 1$ modification and signalling in HCT116 colorectal cancer cells," Scientific Reports, vol. 7, no. 1, p. 9389, 2017.

[80] Y. Zhang, T. Li, L. Zhang et al., "Targeting the functional interplay between endoplasmic reticulum oxidoreductin- $1 \alpha$ and protein disulfide isomerase suppresses the progression of cervical cancer," EBioMedicine, vol. 41, pp. 408-419, 2019.

[81] A. C. Androwiki, L. Camargo Lde, S. Sartoretto et al., "Protein disulfide isomerase expression increases in resistance arteries during hypertension development. Effects on Nox1 NADPH oxidase signaling," Frontiers in Chemistry, vol. 3, p. 24, 2015.

[82] M. Janiszewski, L. R. Lopes, A. O. Carmo et al., "Regulation of $\mathrm{NAD}(\mathrm{P}) \mathrm{H}$ oxidase by associated protein disulfide isomerase in vascular smooth muscle cells," Journal of Biological Chemistry, vol. 280, no. 49, pp. 40813-40819, 2005.

[83] M. Zana, Z. Péterfi, H. A. Kovács et al., "Interaction between p $22^{\text {phox }}$ and Nox4 in the endoplasmic reticulum suggests a unique mechanism of NADPH oxidase complex formation," Free Radical Biology \& Medicine, vol. 116, pp. 41-49, 2018.

[84] D. R. Davydov, "Microsomal monooxygenase as a multienzyme system: the role of P450-P450 interactions," Expert Opinion on Drug Metabolism \& Toxicology, vol. 7, no. 5, pp. 543-558, 2011.

[85] J. Rashba-Step and A. I. Cederbaum, "Generation of reactive oxygen intermediates by human liver microsomes in the presence of NADPH or NADH," Molecular Pharmacology, vol. 45, no. 1, pp. 150-157, 1994.

[86] S. C. Bondy and S. Naderi, "Contribution of hepatic cytochrome P450 systems to the generation of reactive oxygen species," Biochemical Pharmacology, vol. 48, no. 1, pp. 155-159, 1994.

[87] Q. Chen, M. Galleano, and A. I. Cederbaum, "Cytotoxicity and apoptosis produced by arachidonic acid in Hep G2 cells overexpressing human cytochrome P4502E1," Journal of Biological Chemistry, vol. 272, no. 23, pp. 14532-14541, 1997.

[88] M. Ingelman-Sundberg, M. J. Ronis, K. O. Lindros, E. Eliasson, and A. Zhukov, "Ethanol-inducible cytochrome P4502E1: regulation, enzymology and molecular biology," Alcohol and Alcoholism, vol. 2, pp. 131-139, 1994.

[89] M. Friedkin and D. Roberts, "The enzymatic synthesis of nucleosides. I. Thymidine phosphorylase in mammalian tissue," Journal of Biological Chemistry, vol. 207, no. 1, pp. 245-256, 1954.

[90] Y. Y. Elamin, S. Rafee, N. Osman, K. J. O’Byrne, and K. Gately, "Thymidine phosphorylase in cancer; enemy or friend?," Cancer Microenvironment, vol. 9, no. 1, pp. 33-43, 2016.

[91] S. Tabata, M. Yamamoto, H. Goto et al., "Thymidine catabolism promotes NADPH oxidase-derived reactive oxygen species (ROS) signalling in KB and yumoto cells," Scientific Reports, vol. 8, no. 1, article 6760, 2018.
[92] N. S. Brown, A. Jones, C. Fujiyama, A. L. Harris, and R. Bicknell, "Thymidine phosphorylase induces carcinoma cell oxidative stress and promotes secretion of angiogenic factors," Cancer Research, vol. 60, no. 22, pp. 6298-6302, 2000.

[93] A. E. Pegg, "Functions of polyamines in mammals," Journal of Biological Chemistry, vol. 291, no. 29, pp. 14904-14912, 2016.

[94] A. E. Pegg, "Mammalian polyamine metabolism and function,” IUBMB Life, vol. 61, no. 9, pp. 880-894, 2009.

[95] R. A. Casero Jr., T. Murray Stewart, and A. E. Pegg, "Polyamine metabolism and cancer: treatments, challenges and opportunities," Nature Reviews Cancer, vol. 18, no. 11, pp. 681-695, 2018.

[96] N. Seiler, "Polyamine metabolism," Digestion, vol. 46, no. 2, pp. 319-330, 1990.

[97] A. E. Pegg, "Toxicity of polyamines and their metabolic products," Chemical Research in Toxicology, vol. 26, no. 12, pp. 1782-1800, 2013.

[98] H. Xu, R. Chaturvedi, Y. Cheng et al., "Spermine oxidation induced by Helicobacter pylori results in apoptosis and DNA damage: implications for gastric carcinogenesis," Cancer Research, vol. 64, no. 23, pp. 8521-8525, 2004.

[99] R. Chaturvedi, T. de Sablet, R. M. Peek Jr., and K. T. Wilson, "Spermine oxidase, a polyamine catabolic enzyme that links Helicobacter pylori CagA and gastric cancer risk," Gut Microbes, vol. 3, no. 1, pp. 48-56, 2012.

[100] R. Chaturvedi, T. de Sablet, M. Asim et al., "Increased Helicobacter pylori-associated gastric cancer risk in the Andean region of Colombia is mediated by spermine oxidase," Oncogene, vol. 34, no. 26, pp. 3429-3440, 2015.

[101] R. Chaturvedi, M. Asim, M. B. Piazuelo et al., "Activation of EGFR and ERBB2 by Helicobacter pylori results in survival of gastric epithelial cells with DNA damage," Gastroenterology, vol. 146, no. 7, pp. 1739-1751.e14, 2014.

[102] R. V. Purcell, J. Pearson, A. Aitchison, L. Dixon, F. A. Frizelle, and J. I. Keenan, "Colonization with enterotoxigenic Bacteroides fragilis is associated with early-stage colorectal neoplasia," PLoS One, vol. 12, no. 2, article e0171602, 2017.

[103] A. C. Goodwin, C. E. D. Shields, S. Wu et al., "Polyamine catabolism contributes to enterotoxigenic Bacteroides fragilis-induced colon tumorigenesis," Proceedings of the National Academy of Sciences of the United States of America, vol. 108, no. 37, pp. 15354-15359, 2011.

[104] A. V. Snezhkina, G. S. Krasnov, A. V. Lipatova et al., "The dysregulation of polyamine metabolism in colorectal cancer is associated with overexpression of $\mathrm{c}-\mathrm{Myc}$ and $\mathrm{C} / \mathrm{EBP} \beta$ rather than enterotoxigenic Bacteroides fragilis infection," Oxidative Medicine and Cellular Longevity, vol. 2016, Article ID 2353560, 11 pages, 2016.

[105] A. C. Goodwin, S. Jadallah, A. Toubaji et al., "Increased spermine oxidase expression in human prostate cancer and prostatic intraepithelial neoplasia tissues," The Prostate, vol. 68, no. 7, pp. 766-772, 2008.

[106] O. A. Smirnova, T. A. Keinanen, O. N. Ivanova et al., "Hepatitis $\mathrm{C}$ virus alters metabolism of biogenic polyamines by affecting expression of key enzymes of their metabolism," Biochemical and Biophysical Research Communications, vol. 483, no. 2, pp. 904-909, 2017.

[107] T. Hu, D. Sun, J. Zhang et al., "Spermine oxidase is upregulated and promotes tumor growth in hepatocellular 
carcinoma," Hepatology Research, vol. 48, no. 12, pp. 967977, 2018.

[108] O. N. Ivanova, A. V. Snezhkina, G. S. Krasnov et al., “Activation of polyamine catabolism by $\mathrm{N}^{1}, \mathrm{~N}^{11}$-diethylnorspermine in hepatic HepaRG cells induces dedifferentiation and mesenchymal-like phenotype," Cells, vol. 7, no. 12, p. 275, 2018.

[109] M. Spotheim-Maurizot, S. Ruiz, R. Sabattier, and M. Charlier, "Radioprotection of DNA by polyamines," International Journal of Radiation Biology, vol. 68, no. 5, pp. 571-577, 1995.

[110] H. C. Ha, N. S. Sirisoma, P. Kuppusamy, J. L. Zweier, P. M. Woster, and R. A. Casero Jr., "The natural polyamine spermine functions directly as a free radical scavenger," Proceedings of the National Academy of Sciences of the United States of America, vol. 95, no. 19, pp. 11140-11145, 1998.

[111] R. L. Warters, G. L. Newton, P. L. Olive, and R. C. Fahey, "Radioprotection of human cell nuclear DNA by polyamines: radiosensitivity of chromatin is influenced by tightly bound spermine," Radiation Research, vol. 151, no. 3, pp. 354-362, 1999.

[112] T. Douki, Y. Bretonniere, and J. Cadet, "Protection against radiation-induced degradation of DNA bases by polyamines," Radiation Research, vol. 153, no. 1, pp. 29-35, 2000.

[113] B. G. Feuerstein, N. Pattabiraman, and L. J. Marton, "Spermine-DNA interactions: a theoretical study," Proceedings of the National Academy of Sciences of the United States of America, vol. 83, no. 16, pp. 5948-5952, 1986.

[114] H. S. Basu, H. C. A. Schwietert, B. G. Feuerstein, and L. J. Marton, "Effects of variation in the structure of spermine on the association with DNA and the induction of DNA conformational changes," Biochemical Journal, vol. 269, no. 2, pp. 329-334, 1990.

[115] E. Pedreno, A. J. Lopez-Contreras, A. Cremades, and R. Penafiel, "Protecting or promoting effects of spermine on DNA strand breakage induced by iron or copper ions as a function of metal concentration," Journal of Inorganic Biochemistry, vol. 99, no. 10, pp. 2074-2080, 2005.

[116] Y. Ou, S. J. Wang, D. Li, B. Chu, and W. Gu, "Activation of SAT1 engages polyamine metabolism with p53-mediated ferroptotic responses," Proceedings of the National Academy of Sciences of the United States of America, vol. 113, no. 44, pp. E6806-E6812, 2016.

[117] N. Seiler, "Catabolism of polyamines," Amino Acids, vol. 26, no. 3, pp. 217-233, 2004.

[118] T. Bieganski, J. Kusche, W. Lorenz, R. Hesterberg, C. D. Stahlknecht, and K. D. Feussner, "Distribution and properties of human intestinal diamine oxidase and its relevance for the histamine catabolism," Biochimica et Biophysica Acta (BBA) General Subjects, vol. 756, no. 2, pp. 196-203, 1983.

[119] G. Houen, "Mammalian Cu-containing amine oxidases (CAOs): new methods of analysis, structural relationships, and possible functions," APMIS, vol. 107, no. S96, pp. 5-46, 1999.

[120] A. Keskinege, S. Elgün, and E. Yilmaz, "Possible implications of arginase and diamine oxidase in prostatic carcinoma," Cancer Detection and Prevention, vol. 25, no. 1, pp. 76-79, 2001.

[121] J. Y. Lu, Y. Yang, and Y. J. Liang, "Immunohistochemical study on diamine oxidase in mammary cancer and adenosis," Zhonghua Zhong Liu Za Zhi [Chinese journal of oncology], vol. 16, no. 4, pp. 288-290, 1994.
[122] R. Chanda and A. K. Ganguly, "Diamine-oxidase activity and tissue di- and poly-amine contents of human ovarian, cervical and endometrial carcinoma," Cancer Letters, vol. 89, no. 1-2, pp. 23-28, 1995.

[123] M. Linsalata, F. Russo, A. Cavallini, P. Berloco, and A. Di Leo, "Polyamines, diamine oxidase, and ornithine decarboxylase activity in colorectal cancer and in normal surrounding mucosa," Diseases of the Colon and Rectum, vol. 36, no. 7, pp. 662-667, 1993.

[124] N. E. Borglin and B. Willert, "Increased histaminolytic power of plasma in endometrial adenocarcinoma," Cancer, vol. 15, no. 2, pp. 271-275, 1962.

[125] S. B. Baylin, M. D. Abeloff, K. C. Wieman, J. W. Tomford, and D. S. Ettinger, "Elevated histaminase (diamine oxidase) activity in small-cell carcinoma of the lung," The New England Journal of Medicine, vol. 293, no. 25, pp. 1286-1290, 1975.

[126] A. C. Andersson, S. Henningsson, and J. Jarhult, "Diamine oxidase activity and $\gamma$-aminobutyric acid formation in medullary carcinoma of the thyroid," Agents and Actions, vol. 10 , no. 4 , pp. 299-301, 1980.

[127] T. Namikawa, I. Fukudome, H. Kitagawa, T. Okabayashi, M. Kobayashi, and K. Hanazaki, "Plasma diamine oxidase activity is a useful biomarker for evaluating gastrointestinal tract toxicities during chemotherapy with oral fluorouracil anti-cancer drugs in patients with gastric cancer," Oncology, vol. 82, no. 3, pp. 147-152, 2012.

[128] T. Tsujikawa, K. Uda, T. Ihara et al., "Changes in serum diamine oxidase activity during chemotherapy in patients with hematological malignancies," Cancer Letters, vol. 147, no. 1-2, pp. 195-198, 1999.

[129] E. Holtta, "Oxidation of spermidine and spermine in rat liver: purification and properties of polyamine oxidase," Biochemistry, vol. 16, no. 1, pp. 91-100, 1977.

[130] A. E. Pegg, "Spermidine/spermine- $N^{1}$-acetyltransferase: a key metabolic regulator," American Journal of PhysiologyEndocrinology and Metabolism, vol. 294, no. 6, pp. E9951010, 2008.

[131] Y. Wang and R. A. Casero Jr., "Mammalian polyamine catabolism: a therapeutic target, a pathological problem, or both?" Journal of Biochemistry, vol. 139, no. 1, pp. 17-25, 2006.

[132] Y. Wang, W. Devereux, P. M. Woster, T. M. Stewart, A. Hacker, and R. A. Casero Jr., "Cloning and characterization of a human polyamine oxidase that is inducible by polyamine analogue exposure," Cancer Research, vol. 61, no. 14, pp. 5370-5373, 2001.

[133] S. Vujcic, P. Diegelman, C. J. Bacchi, D. L. Kramer, and C. W. Porter, "Identification and characterization of a novel flavincontaining spermine oxidase of mammalian cell origin," Biochemical Journal, vol. 367, no. 3, pp. 665-675, 2002.

[134] T. Murray-Stewart, Y. Wang, A. Goodwin, A. Hacker, A. Meeker, and R. A. Casero Jr., "Nuclear localization of human spermine oxidase isoforms - possible implications in drug response and disease etiology," The FEBS Journal, vol. 275, no. 11, pp. 2795-2806, 2008.

[135] A. Pledgie, Y. Huang, A. Hacker et al., "Spermine oxidase SMO(PAOh1), Not $N^{1}$-acetylpolyamine oxidase PAO, is the primary source of cytotoxic $\mathrm{H}_{2} \mathrm{O}_{2}$ in polyamine analoguetreated human breast cancer cell lines," Journal of Biological Chemistry, vol. 280, no. 48, pp. 39843-39851, 2005.

[136] F. Stirpe and E. Della Corte, "The regulation of rat liver xanthine oxidase. Conversion in vitro of the enzyme activity 
from dehydrogenase (type D) to oxidase (type O)," Journal of Biological Chemistry, vol. 244, no. 14, pp. 3855-3863, 1969.

[137] T. Nishino and T. Nishino, "The conversion from the dehydrogenase type to the oxidase type of rat liver xanthine dehydrogenase by modification of cysteine residues with fluorodinitrobenzene," Journal of Biological Chemistry, vol. 272, no. 47, pp. 29859-29864, 1997.

[138] T. Nishino, K. Okamoto, B. T. Eger, E. F. Pai, and T. Nishino, "Mammalian xanthine oxidoreductase - mechanism of transition from xanthine dehydrogenase to xanthine oxidase," The FEBS Journal, vol. 275, no. 13, pp. 3278-3289, 2008.

[139] Z. Zhang, D. R. Blake, C. R. Stevens et al., "A reappraisal of xanthine dehydrogenase and oxidase in hypoxic reperfusion injury: the role of $\mathrm{NADH}$ as an electron donor," Free Radical Research, vol. 28, no. 2, pp. 151-164, 1998.

[140] C. M. Harris and V. Massey, "The oxidative half-reaction of xanthine dehydrogenase with NAD; reaction kinetics and steady-state mechanism," Journal of Biological Chemistry, vol. 272, no. 45, pp. 28335-28341, 1997.

[141] T. M. Millar, C. R. Stevens, N. Benjamin, R. Eisenthal, R. Harrison, and D. R. Blake, "Xanthine oxidoreductase catalyses the reduction of nitrates and nitrite to nitric oxide under hypoxic conditions," FEBS Letters, vol. 427, no. 2, pp. 225-228, 1998.

[142] E. Boyland and M. E. Boyland, "Studies in tissue metabolism: lactic dehydrogenase, xanthine oxidase and nucleosidase in tumour and muscle extracts," Biochemical Journal, vol. 29, no. 5, pp. 1097-1101, 1935.

[143] M. G. Battelli, L. Polito, M. Bortolotti, and A. Bolognesi, "Xanthine oxidoreductase in cancer: more than a differentiation marker," Cancer Medicine, vol. 5, no. 3, pp. 546-557, 2016.

[144] E. Kokoglu, A. Belce, E. Ozyurt, and Z. Tepeler, "Xanthine oxidase levels in human brain tumors," Cancer Letters, vol. 50, no. 3, pp. 179-181, 1990.

[145] İ. Durak, C. Ü. Işik, O. Canbolat, Ö. Akyol, and M. Kavutçu, "Adenosine deaminase, 5 ' nucleotidase, xanthine oxidase, superoxide dismutase, and catalase activities in cancerous and noncancerous human laryngeal tissues," Free Radical Biology \& Medicine, vol. 15, no. 6, pp. 681-684, 1993.

[146] H. S. Oztürk, M. Karaayvaz, M. Kacmaz, M. Kavutcu, H. Akgül, and I. Durak, "Activities of the enzymes participating in purine and free-radical metabolism in cancerous human colorectal tissues," Cancer Biochemistry Biophysics, vol. 16, no. 1-2, pp. 157-168, 1998.

[147] D. W. Nebert and D. W. Russell, "Clinical importance of the cytochromes P450," The Lancet, vol. 360, no. 9340, pp. 1155-1162, 2002.

[148] E. G. Hrycay and S. M. Bandiera, "Monooxygenase, peroxidase and peroxygenase properties and reaction mechanisms of cytochrome P450 enzymes," Advances in Experimental Medicine and Biology, vol. 851, pp. 1-61, 2015.

[149] D. Werck-Reichhart and R. Feyereisen, "Cytochromes P450: a success story," Genome Biology, vol. 1, no. 6, article reviews3003.1, 2000.

[150] E. G. Hrycay and S. M. Bandiera, "Involvement of cytochrome $\mathrm{P} 450$ in reactive oxygen species formation and cancer," Advances in Pharmacology, vol. 74, pp. 35-84, 2015.

[151] M. Seliskar and D. Rozman, "Mammalian cytochromes P450-importance of tissue specificity," Biochimica et Bio- physica Acta (BBA) - General Subjects, vol. 1770, no. 3, pp. 458-466, 2007.

[152] Y. S. Bae, H. Oh, S. G. Rhee, and Y. D. Yoo, "Regulation of reactive oxygen species generation in cell signaling," Molecules and Cells, vol. 32, no. 6, pp. 491-509, 2011.

[153] R. C. Zangar, D. R. Davydov, and S. Verma, "Mechanisms that regulate production of reactive oxygen species by cytochrome P450," Toxicology and Applied Pharmacology, vol. 199, no. 3, pp. 316-331, 2004.

[154] A. A. Caro and A. I. Cederbaum, "Oxidative stress, toxicology, and pharmacology of CYP2E1," Annual Review of Pharmacology and Toxicology, vol. 44, no. 1, pp. 27-42, 2004.

[155] W. D. Landry and T. G. Cotter, "ROS signalling, NADPH oxidases and cancer," Biochemical Society Transactions, vol. 42, no. 4, pp. 934-938, 2014.

[156] K. Bedard and K. H. Krause, "The NOX family of ROSgenerating NADPH oxidases: physiology and pathophysiology," Physiological Reviews, vol. 87, no. 1, pp. 245-313, 2007.

[157] K. Block and Y. Gorin, "Aiding and abetting roles of NOX oxidases in cellular transformation," Nature Reviews Cancer, vol. 12, no. 9, pp. 627-637, 2012.

[158] J. N. Moloney, J. Stanicka, and T. G. Cotter, "Subcellular localization of the FLT3-ITD oncogene plays a significant role in the production of NOX- and $\mathrm{p} 22^{\text {phox }}$-derived reactive oxygen species in acute myeloid leukemia," Leukemia Research, vol. 52, pp. 34-42, 2017.

[159] C. T. Tang, X. L. Lin, S. Wu et al., "NOX4-driven ROS formation regulates proliferation and apoptosis of gastric cancer cells through the GLI1 pathway," Cellular Signalling, vol. 46, pp. 52-63, 2018.

[160] S. A. Castaldo, A. P. da Silva, A. Matos et al., "The role of CYBA (p22phox) and catalase genetic polymorphisms and their possible epistatic interaction in cervical cancer," Tumour Biology, vol. 36, no. 2, pp. 909-914, 2015.

[161] H. S. Eun, S. Y. Cho, J. S. Joo et al., "Gene expression of NOX family members and their clinical significance in hepatocellular carcinoma," Scientific Reports, vol. 7, no. 1, p. 11060, 2017.

[162] A. Panday, M. K. Sahoo, D. Osorio, and S. Batra, "NADPH oxidases: an overview from structure to innate immunityassociated pathologies," Cellular \& Molecular Immunology, vol. 12, no. 1, pp. 5-23, 2015.

[163] H. S. Park, H. Y. Jung, E. Y. Park, J. Kim, W. J. Lee, and Y. S. Bae, "Cutting edge: direct interaction of TLR4 with $\mathrm{NAD}(\mathrm{P}) \mathrm{H}$ oxidase 4 isozyme is essential for lipopolysaccharide-induced production of reactive oxygen species and activation of NF- $\kappa \mathrm{B}$," The Journal of Immunology, vol. 173, no. 6, pp. 3589-3593, 2004.

[164] J. H. Joo, J. H. Ryu, C. H. Kim et al., "Dual oxidase 2 is essential for the Toll-like receptor 5-mediated inflammatory response in airway mucosa," Antioxidants \& Redox Signaling, vol. 16, no. 1, pp. 57-70, 2012.

[165] C. S. Yang, D. M. Shin, K. H. Kim et al., "NADPH oxidase 2 interaction with TLR2 is required for efficient innate immune responses to mycobacteria via cathelicidin expression," The Journal of Immunology, vol. 182, no. 6, pp. 3696-3705, 2009.

[166] F. Martinon and J. Tschopp, "Inflammatory caspases and inflammasomes: master switches of inflammation," Cell Death \& Differentiation, vol. 14, no. 1, pp. 10-22, 2007.

[167] F. Bauernfeind, E. Bartok, A. Rieger, L. Franchi, G. Nunez, and V. Hornung, "Cutting edge: reactive oxygen species inhibitors block priming, but not activation, of the NLRP3 
inflammasome," The Journal of Immunology, vol. 187, no. 2, pp. 613-617, 2011.

[168] S. Lipinski, A. Till, C. Sina et al., "DUOX2-derived reactive oxygen species are effectors of NOD2-mediated antibacterial responses," Journal of Cell Science, vol. 122, no. 19, pp. 35223530, 2009.

[169] N. S. R. de Mochel, S. Seronello, S. H. Wang et al., "Hepatocyte $\mathrm{NAD}(\mathrm{P}) \mathrm{H}$ oxidases as an endogenous source of reactive oxygen species during hepatitis $\mathrm{C}$ virus infection," Hepatology, vol. 52, no. 1, pp. 47-59, 2010.

[170] H. E. Boudreau, S. U. Emerson, A. Korzeniowska, M. A. Jendrysik, and T. L. Leto, "Hepatitis C virus (HCV) proteins induce NADPH oxidase 4 expression in a transforming growth factor $\beta$-dependent manner: a new contributor to HCV-induced oxidative stress," Journal of Virology, vol. 83, no. 24, pp. 12934-12946, 2009.

[171] C. Bureau, J. Bernad, N. Chaouche et al., "Nonstructural 3 protein of hepatitis $\mathrm{C}$ virus triggers an oxidative burst in human monocytes via activation of NADPH oxidase," Journal of Biological Chemistry, vol. 276, no. 25, pp. 23077-23083, 2001.

[172] F. Thoren, A. Romero, M. Lindh, C. Dahlgren, and K. Hellstrand, "A hepatitis $\mathrm{C}$ virus-encoded, nonstructural protein (NS3) triggers dysfunction and apoptosis in lymphocytes: role of NADPH oxidase-derived oxygen radicals," Journal of Leukocyte Biology, vol. 76, no. 6, pp. 1180-1186, 2004.

[173] G. Fürstenberger, P. Krieg, K. Müller-Decker, and A. J. R. Habenicht, "What are cyclooxygenases and lipoxygenases doing in the driver's seat of carcinogenesis?," International Journal of Cancer, vol. 119, no. 10, pp. 2247-2254, 2006.

[174] C.-M. Kim, J.-Y. Kim, and J.-H. Kim, "Cytosolic phospholipase $A_{2}$, lipoxygenase metabolites, and reactive oxygen species," BMB Reports, vol. 41, no. 8, pp. 555-559, 2008.

[175] C. Schneider, D. A. Pratt, N. A. Porter, and A. R. Brash, "Control of oxygenation in lipoxygenase and cyclooxygenase catalysis," Chemistry \& Biology, vol. 14, no. 5, pp. 473-488, 2007.

[176] R. N. Dubois, S. B. Abramson, L. Crofford et al., "Cyclooxygenase in biology and disease," The FASEB Journal, vol. 12, no. 12, pp. 1063-1073, 1998.

[177] N. V. Chandrasekharan, H. Dai, K. L. T. Roos et al., "COX-3, a cyclooxygenase-1 variant inhibited by acetaminophen and other analgesic/antipyretic drugs: cloning, structure, and expression," Proceedings of the National Academy of Sciences of the United States of America, vol. 99, no. 21, pp. 13926-13931, 2002.

[178] J. M. Schwab, H. J. Schluesener, R. Meyermann, and C. N. Serhan, "COX-3 the enzyme and the concept: steps towards highly specialized pathways and precision therapeutics?," Prostaglandins, Leukotrienes, and Essential Fatty Acids, vol. 69, no. 5, pp. 339-343, 2003.

[179] H. Parfenova, V. Levine, W. M. Gunther, M. Pourcyrous, and C. W. Leffler, "COX-1 and COX-2 contributions to basal and IL-1 $\beta$-stimulated prostanoid synthesis in human neonatal cerebral microvascular endothelial cells," Pediatric Research, vol. 52, no. 3, pp. 342-348, 2002.

[180] T. Kuwano, S. Nakao, H. Yamamoto et al., "Cyclooxygenase 2 is a key enzyme for inflammatory cytokine-induced angiogenesis," The FASEB Journal, vol. 18, no. 2, pp. 300-310, 2004.
[181] E. Fosslien, "Molecular pathology of cyclooxygenase-2 in neoplasia," Annals of Clinical and Laboratory Science, vol. 30, no. 1, pp. 3-21, 2000.

[182] P. J. Bostrom, V. Aaltonen, K. O. Soderstrom, P. Uotila, and M. Laato, "Expression of cyclooxygenase-1 and -2 in urinary bladder carcinomas in vivo and in vitro and prostaglandin $\mathrm{E}_{2}$ synthesis in cultured bladder cancer cells," Pathology, vol. 33, no. 4, pp. 469-474, 2001.

[183] S. Tomozawa, N. H. Tsuno, E. Sunami et al., "Cyclooxygenase-2 overexpression correlates with tumour recurrence, especially haematogenous metastasis, of colorectal cancer," British Journal of Cancer, vol. 83, no. 3, pp. 324-328, 2000.

[184] M. K. Sackett, I. Bairati, F. Meyer et al., "Prognostic significance of cyclooxygenase-2 overexpression in glottic cancer," Clinical Cancer Research, vol. 14, no. 1, pp. 67-73, 2008.

[185] D. Hwang, D. Scollard, J. Byrne, and E. Levine, "Expression of cyclooxygenase- 1 and cyclooxygenase- 2 in human breast cancer," Journal of the National Cancer Institute, vol. 90, no. 6, pp. 455-460, 1998.

[186] K. J. Sales, A. A. Katz, B. Howard, R. P. Soeters, R. P. Millar, and H. N. Jabbour, "Cyclooxygenase-1 is up-regulated in cervical carcinomas: autocrine/paracrine regulation of cyclooxygenase-2, prostaglandin e receptors, and angiogenic factors by cyclooxygenase-1," Cancer Research, vol. 62, no. 2, pp. 424-432, 2002.

[187] A. J. Wilson, O. Fadare, A. Beeghly-Fadiel et al., "Aberrant over-expression of COX-1 intersects multiple protumorigenic pathways in high-grade serous ovarian cancer," Oncotarget, vol. 6, no. 25, pp. 21353-21368, 2015.

[188] T. Sugimoto, T. Koizumi, T. Sudo et al., "Correlative expression of cyclooxygenase-1 (Cox-1) and human epidermal growth factor receptor type-2 (Her-2) in endometrial cancer," The Kobe Journal of Medical Sciences, vol. 53, no. 5, pp. 177-187, 2007.

[189] S. Sankhasard, N. Lertprasertsuk, U. Vinitketkumnuen, and R. Cressey, "Expression of cyclooxygenase-1 and -2 and clinicopathologic features of colorectal cancer in northern Thailand," Asian Pacific Journal of Cancer Prevention, vol. 5, no. 1, pp. 44-49, 2004.

[190] S. Chariyalertsak, V. Sirikulchayanonta, D. Mayer et al., "Aberrant cyclooxygenase isozyme expression in human intrahepatic cholangiocarcinoma," Gut, vol. 48, no. 1, pp. 80-86, 2001.

[191] A. W. Bach, N. C. Lan, D. L. Johnson et al., "cDNA cloning of human liver monoamine oxidase A and B: molecular basis of differences in enzymatic properties," Proceedings of the National Academy of Sciences of the United States of America, vol. 85, no. 13, pp. 4934-4938, 1988.

[192] D. E. Edmondson, C. Binda, J. Wang, A. K. Upadhyay, and A. Mattevi, "Molecular and mechanistic properties of the membrane-bound mitochondrial monoamine oxidases," Biochemistry, vol. 48, no. 20, pp. 4220-4230, 2009.

[193] R. R. Ramsay and A. Albreht, "Kinetics, mechanism, and inhibition of monoamine oxidase," Journal of Neural Transmission, vol. 125, no. 11, pp. 1659-1683, 2018.

[194] P. F. Fitzpatrick, "Oxidation of amines by flavoproteins," Archives of Biochemistry and Biophysics, vol. 493, no. 1, pp. 13-25, 2010.

[195] M. Bortolato, K. Chen, and J. C. Shih, "Monoamine oxidase inactivation: from pathophysiology to therapeutics," 
Advanced Drug Delivery Reviews, vol. 60, no. 13-14, pp. 1527-1533, 2008.

[196] D. Maggiorani, N. Manzella, D. E. Edmondson et al., "Monoamine oxidases, oxidative stress, and altered mitochondrial dynamics in cardiac ageing," Oxidative Medicine and Cellular Longevity, vol. 2017, Article ID 3017947, 8 pages, 2017.

[197] J. B. Wu, C. Shao, X. Li et al., "Monoamine oxidase A mediates prostate tumorigenesis and cancer metastasis," The Journal of Clinical Investigation, vol. 124, no. 7, pp. 2891-2908, 2014.

[198] F. Liu, L. Hu, Y. Ma et al., "Increased expression of monoamine oxidase $\mathrm{A}$ is associated with epithelial to mesenchymal transition and clinicopathological features in non-small cell lung cancer," Oncology Letters, vol. 15, no. 3, pp. 32453251, 2018.

[199] L. True, I. Coleman, S. Hawley et al., "A molecular correlate to the Gleason grading system for prostate adenocarcinoma," Proceedings of the National Academy of Sciences of the United States of America, vol. 103, no. 29, pp. 10991-10996, 2006.

[200] W. Y. Sun, J. Choi, Y. J. Cha, and J. S. Koo, "Evaluation of the expression of amine oxidase proteins in breast cancer," International Journal of Molecular Sciences, vol. 18, no. 12, p. 2775, 2017.

[201] D. M. Peehl, M. Coram, H. Khine, S. Reese, R. Nolley, and H. Zhao, "The significance of monoamine oxidase-A expression in high grade prostate cancer," The Journal of Urology, vol. 180, no. 5, pp. 2206-2211, 2008.

[202] J. Li, X. M. Yang, Y. H. Wang et al., "Monoamine oxidase A suppresses hepatocellular carcinoma metastasis by inhibiting the adrenergic system and its transactivation of EGFR signaling," Journal of Hepatology, vol. 60, no. 6, pp. 1225-1234, 2014.

[203] L. Huang, G. Frampton, A. Rao et al., "Monoamine oxidase A expression is suppressed in human cholangiocarcinoma via coordinated epigenetic and IL-6-driven events," Laboratory Investigation, vol. 92, no. 10, pp. 1451-1460, 2012.

[204] L. A. Rybaczyk, M. J. Bashaw, D. R. Pathak, and K. Huang, "An indicator of cancer: downregulation of monoamine oxidase-A in multiple organs and species," BMC Genomics, vol. 9, no. 1, p. 134, 2008.

[205] A. K. Sood, R. Bhatty, A. A. Kamat et al., "Stress hormonemediated invasion of ovarian cancer cells," Clinical Cancer Research, vol. 12, no. 2, pp. 369-375, 2006.

[206] K. S. R. Sastry, Y. Karpova, S. Prokopovich et al., "Epinephrine protects cancer cells from apoptosis via activation of cAMP-dependent protein kinase and BAD phosphorylation," Journal of Biological Chemistry, vol. 282, no. 19, pp. 1409414100, 2007.

[207] X. Grau-Bove, I. Ruiz-Trillo, and F. Rodriguez-Pascual, "Origin and evolution of lysyl oxidases," Scientific Reports, vol. 5, no. 1, article 10568, 2015.

[208] J. Xu, D. Li, X. Li et al., "67 laminin receptor promotes the malignant potential of tumour cells up-regulating lysyl oxidase-like 2 expression in cholangiocarcinoma," Digestive and Liver Disease, vol. 46, no. 8, pp. 750-757, 2014.

[209] J. S. Park, J. H. Lee, Y. S. Lee, J. K. Kim, S. M. Dong, and D. S. Yoon, "Emerging role of LOXL2 in the promotion of pancreas cancer metastasis," Oncotarget, vol. 7, no. 27, pp. 42539-42552, 2016.

[210] Y. H. Shih, K. W. Chang, M. Y. Chen et al., "Lysyl oxidase and enhancement of cell proliferation and angiogenesis in oral squamous cell carcinoma," Head \& Neck, vol. 35, no. 2, pp. 250-256, 2013.

[211] A. Albinger-Hegyi, S. J. Stoeckli, S. Schmid et al., "Lysyl oxidase expression is an independent marker of prognosis and a predictor of lymph node metastasis in oral and oropharyngeal squamous cell carcinoma (OSCC)," International Journal of Cancer, vol. 126, no. 11, pp. 2653-2662, 2010.

[212] L. Peng, Y. L. Ran, H. Hu et al., "Secreted LOXL2 is a novel therapeutic target that promotes gastric cancer metastasis via the Src/FAK pathway," Carcinogenesis, vol. 30, no. 10, pp. 1660-1669, 2009.

[213] N. Scola and T. Gorogh, "LOXL4 as a selective molecular marker in primary and metastatic head/neck carcinoma," Anticancer Research, vol. 30, no. 11, pp. 4567-4571, 2010.

[214] C. Leo, C. Cotic, V. Pomp, D. Fink, and Z. Varga, "Overexpression of Lox in triple-negative breast cancer," Annals of Diagnostic Pathology, vol. 34, pp. 98-102, 2018.

[215] A. Nakanishi, Y. Wada, Y. Kitagishi, and S. Matsuda, "Link between PI3K/AKT/PTEN Pathway and NOX Proteinin Diseases," Aging and Disease, vol. 5, no. 3, pp. 203-211, 2014.

[216] V. Alvarez-Garcia, Y. Tawil, H. M. Wise, and N. R. Leslie, "Mechanisms of PTEN loss in cancer: it's all about diversity," Seminars in Cancer Biology, 2019.

[217] N. Chalhoub and S. J. Baker, "PTEN and the PI3-kinase pathway in cancer," Annual Review of Pathology, vol. 4, no. 1, pp. 127-150, 2009.

[218] J. El-Benna, P. M. C. Dang, M. A. Gougerot-Pocidalo, J. C. Marie, and F. Braut-Boucher, "p47phox, the phagocyte NADPH oxidase/NOX2 organizer: structure, phosphorylation and implication in diseases," Experimental \& Molecular Medicine, vol. 41, no. 4, pp. 217-225, 2009.

[219] N. R. Leslie, D. Bennett, Y. E. Lindsay, H. Stewart, A. Gray, and C. P. Downes, "Redox regulation of PI 3-kinase signalling via inactivation of PTEN," The EMBO Journal, vol. 22, no. 20, pp. 5501-5510, 2003.

[220] R. Rastogi, X. Geng, F. Li, and Y. Ding, "NOX activation by subunit interaction and underlying mechanisms in disease," Frontiers in Cellular Neuroscience, vol. 10, p. 301, 2017.

[221] K. K. Haagenson and G. S. Wu, "Mitogen activated protein kinase phosphatases and cancer," Cancer Biology \& Therapy, vol. 9, no. 5, pp. 337-340, 2010.

[222] A. Caretta and C. Mucignat-Caretta, "Protein kinase a in cancer," Cancers, vol. 3, no. 1, pp. 913-926, 2011.

[223] R. Kumar, A. E. Gururaj, and C. J. Barnes, "p21-activated kinases in cancer," Nature Reviews Cancer, vol. 6, no. 6, pp. 459-471, 2006.

[224] B. Vurusaner, G. Poli, and H. Basaga, "Tumor suppressor genes and ROS: complex networks of interactions," Free Radical Biology \& Medicine, vol. 52, no. 1, pp. 7-18, 2012.

[225] S. P. Hussain, P. Amstad, P. He et al., "p53-induced up-regulation of MnSOD and GPx but not catalase increases oxidative stress and apoptosis," Cancer Research, vol. 64, no. 7, pp. 2350-2356, 2004.

[226] M. Tan, S. Li, M. Swaroop, K. Guan, L. W. Oberley, and Y. Sun, "Transcriptional activation of the human glutathione peroxidase promoter by p53," Journal of Biological Chemistry, vol. 274, no. 17, pp. 12061-12066, 1999.

[227] A. V. Budanov, A. A. Sablina, E. Feinstein, E. V. Koonin, and P. M. Chumakov, "Regeneration of peroxiredoxins by p53regulated sestrins, homologs of bacterial AhpD," Science, vol. 304, no. 5670, pp. 596-600, 2004. 
[228] S. Suzuki, T. Tanaka, M. V. Poyurovsky et al., "Phosphateactivated glutaminase (GLS2), a p53-inducible regulator of glutamine metabolism and reactive oxygen species," Proceedings of the National Academy of Sciences of the United States of America, vol. 107, no. 16, pp. 74617466, 2010.

[229] K. Bensaad, A. Tsuruta, M. A. Selak et al., "TIGAR, a p53inducible regulator of glycolysis and apoptosis," Cell, vol. 126, no. 1, pp. 107-120, 2006.

[230] C. A. Hu, W. W. Lin, and D. Valle, "Cloning, characterization, and expression of cDNAs encoding human $\Delta_{1}$-pyrroline-5-carboxylate dehydrogenase," Journal of Biological Chemistry, vol. 271, no. 16, pp. 9795-9800, 1996.

[231] K. A. Yoon, Y. Nakamura, and H. Arakawa, "Identification of ALDH4 as a p53-inducible gene and its protective role in cellular stresses," Journal of Human Genetics, vol. 49, no. 3, pp. 134-140, 2004.

[232] Z. Liu, H. Lu, H. Shi et al., "PUMA overexpression induces reactive oxygen species generation and proteasomemediated stathmin degradation in colorectal cancer cells," Cancer Research, vol. 65, no. 5, pp. 1647-1654, 2005.

[233] M. Giorgio, E. Migliaccio, F. Orsini et al., "Electron transfer between cytochrome $\mathrm{c}$ and $\mathrm{p} 66^{\text {Shc }}$ generates reactive oxygen species that trigger mitochondrial apoptosis," Cell, vol. 122, no. 2, pp. 221-233, 2005.

[234] K. Polyak, Y. Xia, J. L. Zweier, K. W. Kinzler, and B. Vogelstein, "A model for p53-induced apoptosis," Nature, vol. 389, no. 6648, pp. 300-305, 1997.

[235] A. A. Sablina, A. V. Budanov, G. V. Ilyinskaya, L. S. Agapova, J. E. Kravchenko, and P. M. Chumakov, "The antioxidant function of the p53 tumor suppressor," Nature Medicine, vol. 11, no. 12, pp. 1306-1313, 2005.

[236] M. G. Vander Heiden, L. C. Cantley, and C. B. Thompson, "Understanding the Warburg effect: the metabolic requirements of cell proliferation," Science, vol. 324, no. 5930, pp. 1029-1033, 2009.

[237] O. Warburg, "On the origin of cancer cells," Science, vol. 123, no. 3191, pp. 309-314, 1956.

[238] X. Tong, F. Zhao, and C. B. Thompson, "The molecular determinants of de novo nucleotide biosynthesis in cancer cells," Current Opinion in Genetics \& Development, vol. 19, no. 1, pp. 32-37, 2009.

[239] C. M. Labak, P. Y. Wang, R. Arora et al., "Glucose transport: meeting the metabolic demands of cancer, and applications in glioblastoma treatment," American Journal of Cancer Research, vol. 6, no. 8, pp. 1599-1608, 2016.

[240] E. A. Pudova, A. V. Kudryavtseva, M. S. Fedorova et al., "HK3 overexpression associated with epithelial-mesenchymal transition in colorectal cancer," BMC Genomics, vol. 19, Supplement 3, p. 113, 2018.

[241] G. S. Krasnov, A. A. Dmitriev, A. F. Sadtritdinova et al., "Evaluation of gene expression of hexokinases in colorectal cancer with the use of bioinformatics methods," Biofizika, vol. 60, no. 6, pp. 1050-1056, 2015.

[242] N. Y. Oparina, A. V. Snezhkina, A. F. Sadritdinova et al., "Differential expression of genes that encode glycolysis enzymes in kidney and lung cancer in humans," Russian Journal of Genetics, vol. 49, no. 7, pp. 707-716, 2013.

[243] G. S. Krasnov, A. A. Dmitriev, A. V. Snezhkina, and A. V. Kudryavtseva, "Deregulation of glycolysis in cancer: glyceraldehyde-3-phosphate dehydrogenase as a therapeutic target," Expert Opinion on Therapeutic Targets, vol. 17, no. 6, pp. 681-693, 2013.

[244] A. V. Snezhkina, G. S. Krasnov, S. O. Zhikrivetskaya et al., "Overexpression of microRNAs miR-9,-98, and-199 correlates with the downregulation of $H K 2$ expression in colorectal cancer," Molecular Biology, vol. 52, no. 2, pp. 190-199, 2018.

[245] A. V. Snezhkina, G. S. Krasnov, A. R. Zaretsky et al., "Differential expression of alternatively spliced transcripts related to energy metabolism in colorectal cancer," BMC Genomics, vol. 17, Supplement 14, p. 1011, 2016.

[246] M. S. Fedorova, A. V. Kudryavtseva, V. A. Lakunina et al., "Downregulation of OGDHL expression is associated with promoter hypermethylation in colorectal cancer," Molecular Biology, vol. 49, no. 4, pp. 608-617, 2015.

[247] M. Lee and J. H. Yoon, "Metabolic interplay between glycolysis and mitochondrial oxidation: the reverse Warburg effect and its therapeutic implication," World Journal of Biological Chemistry, vol. 6, no. 3, pp. 148-161, 2015.

[248] P. J. Fernandez-Marcos and S. Nobrega-Pereira, "NADPH: new oxygen for the ROS theory of aging," Oncotarget, vol. 7, no. 32, pp. 50814-50815, 2016.

[249] R. C. Stanton, "Glucose-6-phosphate dehydrogenase, NADPH, and cell survival," IUBMB Life, vol. 64, no. 5, pp. 362-369, 2012.

[250] D. Holten, D. Procsal, and H. L. Chang, "Regulation of pentose phosphate pathway dehydrogenases by $\mathrm{NADP}^{+}$/NADPH ratios," Biochemical and Biophysical Research Communications, vol. 68, no. 2, pp. 436-441, 1976.

[251] E. Mullarky and L. C. Cantley, "Diverting glycolysis to combat oxidative stress," in Innovative Medicine: Basic Research and Development, K. Nakao, N. Minato, and S. Uemoto, Eds., pp. 3-23, Springer, Tokyo, 2015.

[252] Z. Ghanbari Movahed, M. Rastegari-Pouyani, M. H. Mohammadi, and K. Mansouri, "Cancer cells change their glucose metabolism to overcome increased ROS: One step from cancer cell to cancer stem cell?," Biomedicine \& Pharmacotherapy, vol. 112, article 108690, 2019.

[253] X. Chen, M. Song, B. Zhang, and Y. Zhang, "Reactive oxygen species regulate $\mathrm{T}$ cell immune response in the tumor microenvironment," Oxidative Medicine and Cellular Longevity, vol. 2016, Article ID 1580967, 10 pages, 2016.

[254] T. L. Whiteside, "The tumor microenvironment and its role in promoting tumor growth," Oncogene, vol. 27, no. 45, pp. 5904-5912, 2008.

[255] P. Carmeliet and R. K. Jain, "Molecular mechanisms and clinical applications of angiogenesis," Nature, vol. 473, no. 7347, pp. 298-307, 2011.

[256] J. Frisch, A. Angenendt, M. Hoth, L. Prates Roma, and A. Lis, "STIM-Orai channels and reactive oxygen species in the tumor microenvironment," Cancers, vol. 11, no. 4, p. 457, 2019.

[257] R. Bhome, M. D. Bullock, H. A. Al Saihati et al., "A top-down view of the tumor microenvironment: structure, cells and signaling," Frontiers in Cell and Developmental Biology, vol. 3, p. 33, 2015.

[258] M. Wang, J. Zhao, L. Zhang et al., "Role of tumor microenvironment in tumorigenesis," Journal of Cancer, vol. 8, no. 5, pp. 761-773, 2017.

[259] Y. Sun, "Tumor microenvironment and cancer therapy resistance," Cancer Letters, vol. 380, no. 1, pp. 205-215, 2016. 
[260] Y. Yu and J. Cui, "Present and future of cancer immunotherapy: a tumor microenvironmental perspective," Oncology Letters, vol. 16, no. 4, pp. 4105-4113, 2018.

[261] G. P. Bienert, J. K. Schjoerring, and T. P. Jahn, "Membrane transport of hydrogen peroxide," Biochimica et Biophysica Acta (BBA) - Biomembranes, vol. 1758, no. 8, pp. 994-1003, 2006.

[262] T. Henzler and E. Steudle, "Transport and metabolic degradation of hydrogen peroxide in Chara corallina: model calculations and measurements with the pressure probe suggest transport of $\mathrm{H}_{2} \mathrm{O}_{2}$ across water channels," Journal of Experimental Botany, vol. 51, no. 353, pp. 2053-2066, 2000.

[263] M. Hara-Chikuma, H. Satooka, S. Watanabe et al., "Aquaporin-3-mediated hydrogen peroxide transport is required for NF- $\kappa \mathrm{B}$ signalling in keratinocytes and development of psoriasis," Nature Communications, vol. 6, no. 1, article 7454, 2015.

[264] M. O. Laukkanen, "Extracellular superoxide dismutase: growth promoter or tumor suppressor?," Oxidative Medicine and Cellular Longevity, vol. 2016, Article ID 3612589, 9 pages, 2016.

[265] W. M. Nauseef, "Detection of superoxide anion and hydrogen peroxide production by cellular NADPH oxidases," Biochimica et Biophysica Acta (BBA) - General Subjects, vol. 1840, no. 2, pp. 757-767, 2014.

[266] G. Bauer, "Targeting extracellular ROS signaling of tumor cells," Anticancer Research, vol. 34, no. 4, pp. 1467-1482, 2014.

[267] J. S. K. Chan, M. J. Tan, M. K. Sng et al., "Cancer-associated fibroblasts enact field cancerization by promoting extratumoral oxidative stress," Cell Death \& Disease, vol. 8, no. 1, article e2562, 2018.

[268] L. M. Paardekooper, W. Vos, and G. Bogaart, "Oxygen in the tumor microenvironment: effects on dendritic cell function," Oncotarget, vol. 10, no. 8, pp. 883-896, 2019.

[269] E. Birben, U. M. Sahiner, C. Sackesen, S. Erzurum, and O. Kalayci, "Oxidative stress and antioxidant defense," The World Allergy Organization Journal, vol. 5, no. 1, pp. 9-19, 2012.

[270] A. N. Onyango, "Endogenous generation of singlet oxygen and ozone in human and animal tissues: mechanisms, biological significance, and influence of dietary components," Oxidative Medicine and Cellular Longevity, vol. 2016, Article ID 2398573, 22 pages, 2016. 


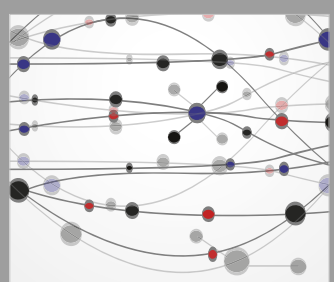

The Scientific World Journal
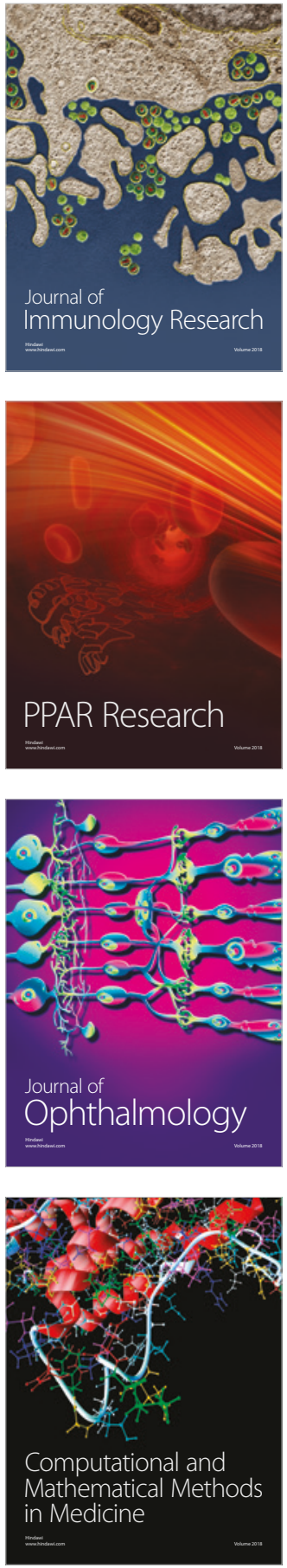

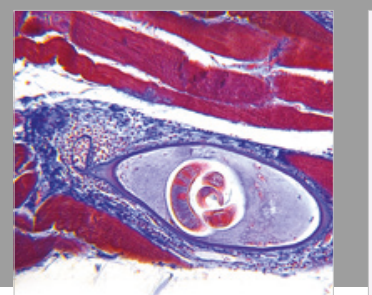

Gastroenterology Research and Practice

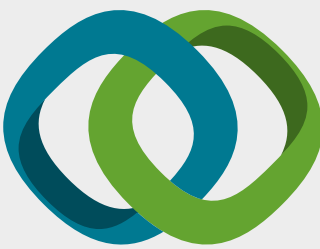

\section{Hindawi}

Submit your manuscripts at

www.hindawi.com
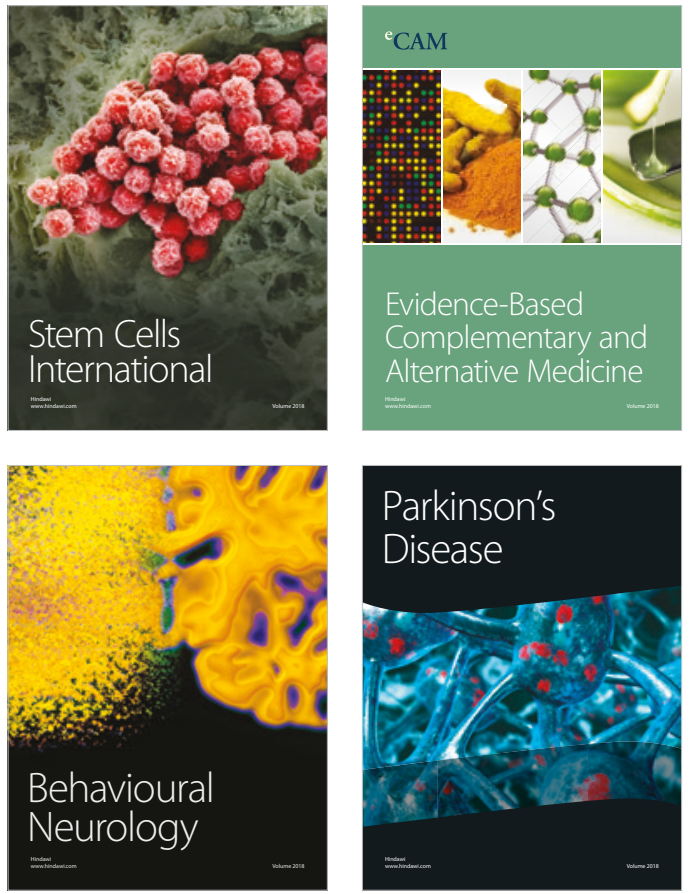

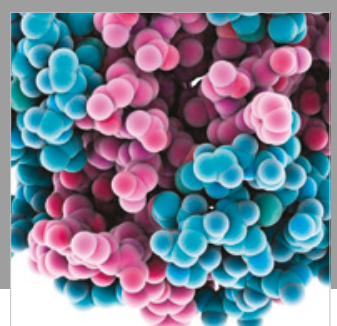

ournal of

Diabetes Research

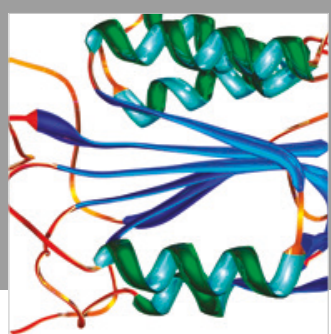

Disease Markers
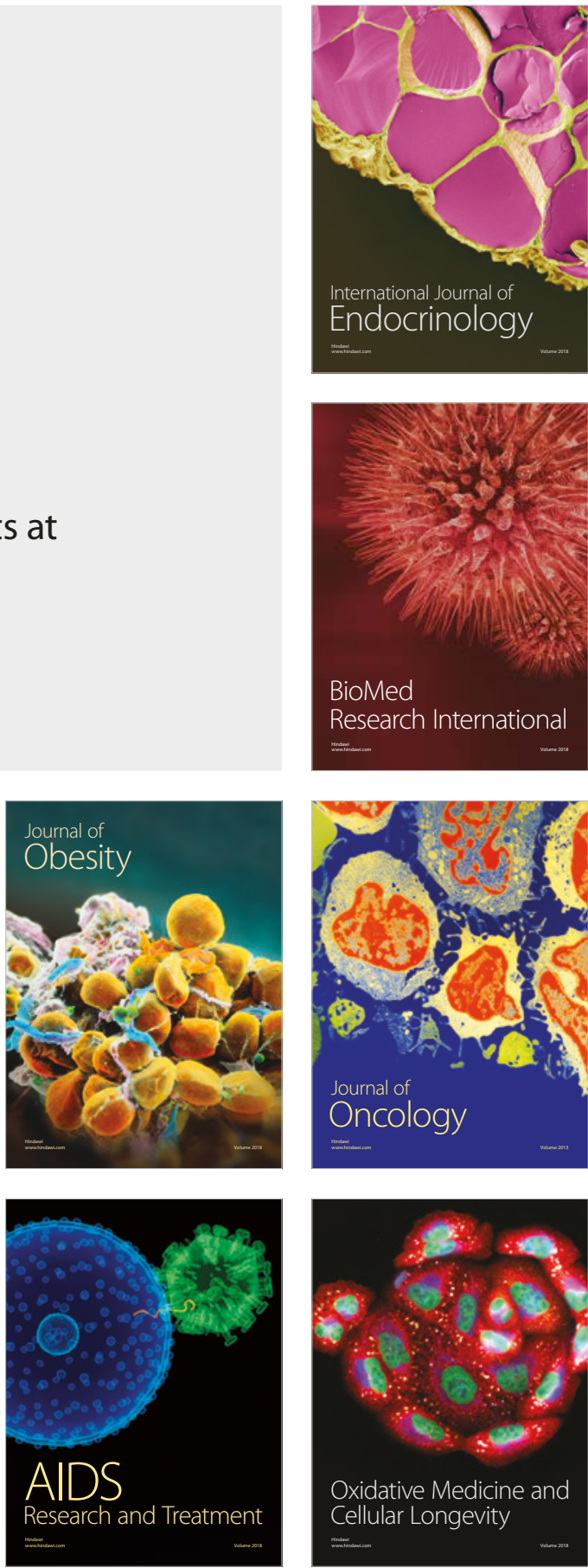